\title{
THE CHANGES THAT OCCURRED IN LAND COVER IN POSTCOMMUNIST COUNTRIES IN CENTRAL EUROPE
}

\author{
DUŠAN ROMPORTL* and PETR KUNA
}

\begin{abstract}
Department of Physical Geography and Geoecology, Faculty of Science, Charles University, Albertov 6, 12843 Prague
* Corresponding author: dusan@natur.cuni.cz
\end{abstract}

\begin{abstract}
Central European landscape has undergone dramatic changes during the last decades. Big changes in the political and economic systems resulted in a large-scale transformation in land use, especially in the agricultural and silvicultural sectors. At the same time, significant changes in urban regions were recorded. In order to quantify and compare the most important processes in land cover changes, we analyzed so-called land cover flows within four post-communist countries in Central Europe - Czech Republic, Slovakia, Poland and Hungary - using CORINE Land Cover databases for 1990, 2000 and 2006. Contradictory processes in landscape change were recorded such as large scale agricultural extensification vs. intensification, or afforestation vs. deforestation. Moreover, there are significant regional differences in the changes in spatial patterns.
\end{abstract}

Keywords: land cover changes, Central Europe, typology

\section{Introduction}

There is no part of the Earth's surface that has not been influenced by human activities. Each type of landscape, natural, cultural and urbanized, is continuously changing and evolving. Understanding the causes, principles and possible aftermaths of these changes in land cover is especially important mainly for making effective decisions about landscape management and its use without causing irreversible loss of valuable environments.

Some of the key factors affecting the global environment are changes in land cover occurring at all levels from local to regional and global. Landscape changes are caused by both natural processes and human activities. The mutual interaction of these factors creates a cultural landscape. Landscape changes are usually considered as positive and/or negative. This depends on the overall context of the landscape. They can result in a decline in biodiversity and loss of the identity of the existing landscape. On the other hand, they generate very valuable habitats and ecosystems. In addition to completely new processes, the termination or temporary interruption of changes in landscape may also result in a transformation of the landscape - for example, abandonment of an agricultural landscape and leaving it to spontaneous development. This usually results in the spread of trees in open habitats, and ultimately to a climax forest. The most important factor here is an undisturbed process of natural succesion. Therefore, understanding landscape development is an important part of caring for landscapes.

\section{Materials and Methods}

The analysis of changes in land cover decribed in this paper is focused on four countries in the region of Central
Europe, Czech Republic, Slovakia, Hungary and Poland. The changes in land cover were based on six elementary processes of changes in landscape that occur frequently in Central Europe: sub/urbanisation, intensification of agriculture, extensification of agriculture, afforestation, deforestation and construction of water bodies. For their precise definition see Romportl et al. (2010). Identification of changes in land cover was based on Feranec et al. (2010) - see Fig. 1.

For assessing the changes in land cover we used the database CORINE Land Cover (CLC) created by the European Environmental Agency (EEA) in cooperation with other European Union institutions responsible for environmental protection. CLC consists of detailed maps of land cover at a scale of 1:100,000. Land cover is divided into 44 classes (Büttner et al. 2012). Currently, databases for 3 horizons, 1990, 2000 and 2006, exist for individual states. Another types of data represent the change databases for the periods 1990-2000 and 2000-2006. They record increases or decreases in the area of different classes of land cover between two reference periods. The basis for the state databases CLC are Landsat satellite images with a spatial resolution of 25 meters. The minimum unit for land cover inventory is $25 \mathrm{ha}$. Change databases include only contiguous polygons with a minimum size of 5 ha (Büttner et al. 2012).

The result of the unification of all the changes in land cover was a total of 320 types of changes of land cover in the case of CLC 1990-2000, and 240 for CLC 2000-2006, respectively. Using the scheme shown in Fig. 1, they were ranked among the following six processes of land cover changes (LCF1-Sub/urbanisation, LCF2-Intensification of agriculture, LCF3-Extensification of agriculture, LCF4-Afforestation, LCF5-Deforestation, LCF6-Construction of water bodies). During the identification of the individual processes, there were some cases that could 


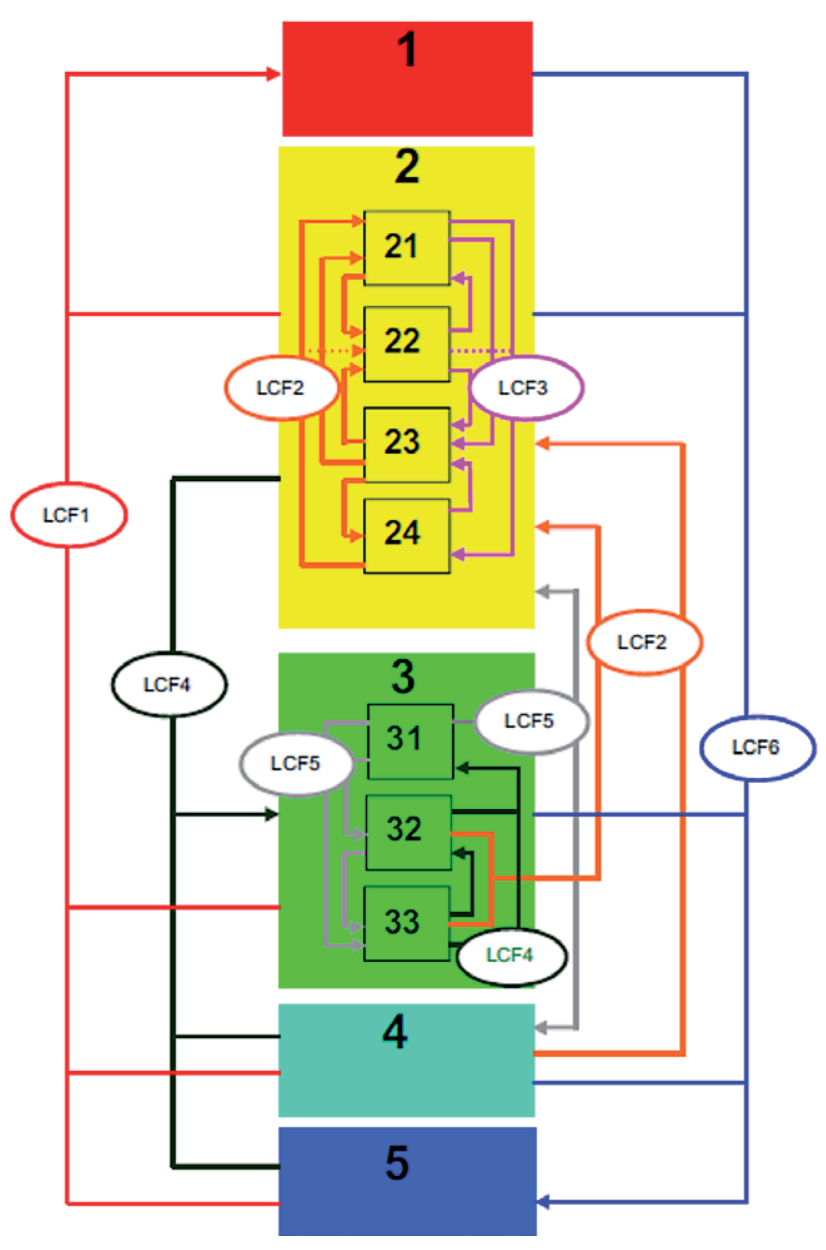

CORINE land cover nomenclature First level

Main land cover chage flows

\begin{tabular}{|c|c|}
\hline 1 & Artificial area \\
\hline 2 & Agricultural area \\
\hline 3 & Forest and semi natural area \\
\hline 4 & Wetlands \\
\hline 5 & Water bodies \\
\hline
\end{tabular}

- Urbanisation (LCF1)

- Intensification of agriculture (LCF2)

- Extensification of agriculture (LCF3)

- Afforestation (LCF4)

- Deforestation (LCF5)

- Water bodies construction (LCF6)

Fig. 1 Relation between changes in land cover and CORINE Land Cove classes (Feranec et al. 2010).

not be classified using this scheme. For example, the transformation of class 222-Fruit trees and berry plantations to class 221-Vineyards or that of class 213-Rice fields to class 211-Non-irrigated arable land. These changes in land cover could not be classified using any of the basic processes of changes in land cover. In addition, they constitute only a very small part of the total area. Therefore, they were excluded from the analysis. The result was thus 305 (CLC 1990-2000) and 233 (CLC 2000-2006) types of changes in land cover.

In addition to several characteristics (total area and proportion of each process in relation to other types of changes in land cover) the key point of analysis was the determination of the area of each change in land cover in terms of the surface of a regular square grid. EEA grid with a field size $100 \mathrm{~km}^{2}$ was used as a reference. The regular square grid was limited by the shape of the area of in- terest, which caused the size of some fields to be reduced to a few square kilometers. Therefore, it was necessary to set a limit to field size, for which it was still possible to calculate specific characteristics. In this case, all fields with an area of less than $10 \mathrm{~km}^{2}$ were excluded from the analysis. This step did not have a negative affect on the results of our analysis.

Maps are of areas where the proportion of the process of change in land cover on the surface of the grid is higher or lower than the average for the region or where the process is entirely absent.

The typology of changes in land cover was done by a using cluster analysis to assess the changes in landscape. It was based on identifying those landscapes showing marked changes in land cover. The analysis was made using function "cluster". Clustering using k-means with 5 clusters was used. Consequently, it was necessary to determine which process of change in land cover was associated with each cluster. Always one cluster was associated with landscape where no changes occurred.

The six processes of changes in land cover based on the database CORINE Land Cover 1990-2000 and 2000-2006 are described below (see Romportl et al. 2010):

Sub/urbanisation (LCF 1) - assessed as an increase in urban areas (categories 111-Continuous urban fabric and 112-Discontinuous urban fabric) and Industrial, commercial and transport areas (categories 121-Industrial or commercial units, 122-Road and rail networks and associated land and 124-Airports) at the expense of other classes.

Intensification of agriculture (LCF 2) - Process of changes in landscape in terms of a change in any land cover category to either the class 211-Arable land or 221-Vineyards.

Extensification of agriculture (LCF 3) - Assessed as in terms of a change form categories 211-Arable land and 221-Vineyards to other land cover classes except urban, water and mining areas.

Afforestation (LCF 4) - Assessed in terms of a change of any land cover category to the classes 311-Deciduous forests, 312-Coniferous forests, 313-Mixed forests or 324-Low forest vegetation. There are two possible options for assessing the process of afforestation. The difference depends on initial state, which is or is not class 324-Low forest vegetation.

Deforestation (LCF 5) - Assessed in terms of a change from categories 311-Deciduous forests, 312-Coniferous forests and 313-Mixed forests to any other land cover classes, except class 324-Low forest vegetation.

Construction of water bodies (LCF 6) - Assessed in terms of a change in any land cover category to class 511-Water courses and 512-Water bodies.

Only the above-described basic processes of changes in land cover were included to the analysis. They are the most common cause of changes in landscape. Feranec et al. (2010) refers to other processes of changes in land cover as marginal. For example, human activities associated 
with the exploitation of natural resources (mining and subsequent recultivation of mining areas). These processes were not included in the analysis.

\section{Results}

The results of the analysis show that the area that underwent a change in land use was $13,738.37 \mathrm{~km}^{2}$ during the first period $1990-2000$ and was $6,793.64 \mathrm{~km}^{2}$ in the second period 2000-2006. Detailed overview of all the processes in the changes in land cover is shown in Tables 1 and 2. While the largest change in land cover was due to afforestation during both periods, in second place was the extensification of agriculture in the first period and deforestation in the second period.

Immediately after the political changes in 1989, there were efforts to correct insensitive changes inflicted on the landscape during the communist era. The following period was characterized by new methods and principles in landscape management. According to the EEA Land Accounts for Europe 1990-2000 Report (EEA Technical Report no. 11/2006) and Feranec et al. (2000) the most significant processes were afforestation but also deforestation, extensification of agriculture in areas with less fertile soils, intensification of agriculture and urban sprawl connected with the growth in urban and industrial areas.

During the period 1990-2000, the largest area of change in land cover was detected in the Czech Republic.
Changes in landscape affected an area of $5,095.16 \mathrm{~km}^{2}$, which is $37.09 \%$ of total area subject to changes and $6.46 \%$ of the area of this country. In the period 2000 2006 the greatest area of changes in land cover occurred in Hungary $\left(2,649.53 \mathrm{~km}^{2}\right)$. The percentage of the area affected by changes in land cover was $39.00 \%$, which is $2.84 \%$ of the area of this country. Detailed overview of some characteristics is shown in Appendix 1-2.

\section{Sub/urbanisation (LCF 1)}

Another important change in the landscape that has occurred in Central Europe is urbanisation and suburbanisation. A common sign of this type of change in land cover is its close association with the largest cities and major transport routes in the region. The total area affected by this change in land cover was $581.6 \mathrm{~km}^{2}$ in the period $1990-2000$ and increased to $627.7 \mathrm{~km}^{2}$ between 2000 and 2006.

During the period 1990-2000 the extent of the builtup area was the greatest in Poland $\left(250.49 \mathrm{~km}^{2}\right)$. The process of sub/urbanisation was concentrated in the surroundings of big cities, such as Warszawa, Łódź, Poznań, Kutno, Kraków, Görlitz and Wroclaw. In the assessment of the sub/urbanisation process, two cities played a significant role, Gdańsk and Szczecin. Their indisputable importance lies in the fact that they are seaports with a link to international shipping. All these cities are major transport nodes with rapidly developing of built-up areas. Between 2000 and 2006, sub/urbanisation was also significant $\left(254.81 \mathrm{~km}^{2}\right)$. First, it was the development

Table 1 Assessed processes of land cover change in period 1990-2000.

\begin{tabular}{|l|c|c|c|}
\hline Processes of change in land cover (LCF) & Area [km ${ }^{2}$ ] & Percentage of the area LCF [\%] & Percentage of the region* [\%] \\
\hline Sub/urbanisation (LCF 1) & 581.59 & 4.23 & 0.11 \\
\hline Intensification of agriculture (LCF 2) & $1,466.87$ & 10.68 & 0.28 \\
\hline Extensification of agriculture (LCF 3) & $4,138.09$ & 30.12 & 0.78 \\
\hline Afforestation (LCF 4) & $4,564.44$ & 33.22 & 0.86 \\
\hline Deforestation (LCF 5) & $2,769.37$ & 20.16 & 0.52 \\
\hline Artificial water bodies (LCF 6) & 218.02 & 1.59 & 0.04 \\
\hline Total & 13738.38 & 100.00 & 2.58 \\
\hline
\end{tabular}

* Total area of Central Europe is 532,932.66 km².

Table 2 Assessed processes of the changes in land cover in the period 2000-2006.

\begin{tabular}{|c|c|c|c|}
\hline Processes of the changes in land cover (LCF) & Area $\left[\mathrm{km}^{2}\right]$ & Percentage of the area LCF [\%] & Percentage of the region* [\%] \\
\hline Sub/urbanisation (LCF 1) & 627.74 & 9.24 & 0.12 \\
\hline Intensification of agriculture (LCF 2) & 717.19 & 10.56 & 0.14 \\
\hline Extensification of agriculture (LCF 3) & 927.82 & 13.66 & 0.17 \\
\hline Afforestation (LCF 4) & $2,267.36$ & 33.38 & 0.43 \\
\hline Deforestation (LCF 5) & $2,170.51$ & 31.95 & 0.41 \\
\hline Artificial water bodies (LCF 6) & 83.02 & 1.22 & 0.02 \\
\hline Total & $6,793.64$ & 100.00 & 1.28 \\
\hline
\end{tabular}

* Total area of Central Europe is $532,932.66 \mathrm{~km}^{2}$. 


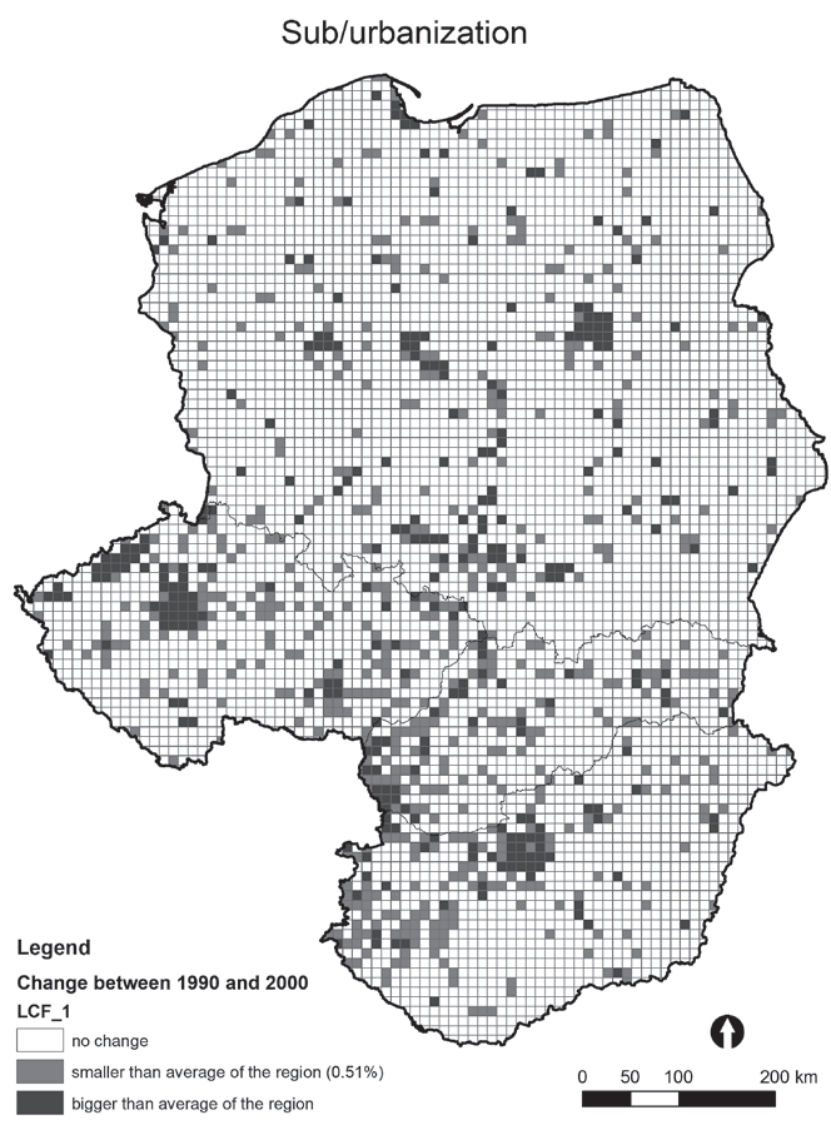

Fig. 2 Process of sub/urbanisation (1990-2000).

of transport networks and commercial and industrial zones within these cities. This type of sub/urbanisation was most distinct in Poland. For example, it was the A2 between Konin and Łódź, and A1 between Gdaňsk and Łódź in central Poland, and the route between Konin and Wroclaw. In addition, within big cities the process of sub/urbanisation also continued.

In the Czech Republic, sub/urbanisation affected an area of $161.64 \mathrm{~km}^{2}$. This type of change in land cover occurred mainly in big cities, in particular in Praha and in some regional capitals and other cities such as Liberec, Karlovy Vary and Sokolov, Plzeň, České Budějovice, Jihlava a Třebíč, Brno, Olomouc and Opava. On the other hand, Ostrava did not follow this trend because of this period there was a decrease in heavy industry and mining. Another area significantly affected by sub/urbanisation is the region of Podkrušnohoří (Chomutov, Most). In the Czech Republic, there was a decrease in the area in the period 2000-2006 (144.48 $\left.\mathrm{km}^{2}\right)$. Significant changes in land cover were associated with both residential and commercial sub/urbanisation. The first of which was typical for regional capital cities (Ústí nad Labem, Karlovy Vary, Plzeň, Pardubice) and the surroundings of Praha, such as Kladno, Rakovník, Beroun with their large satelite residential areas.

A smaller area of sub/urbanisation was recorded between 1990 and 2000 in Hungary $\left(110.36 \mathrm{~km}^{2}\right)$, which was mainly in Budapest, Székesfehérvár, Eger and Mis-

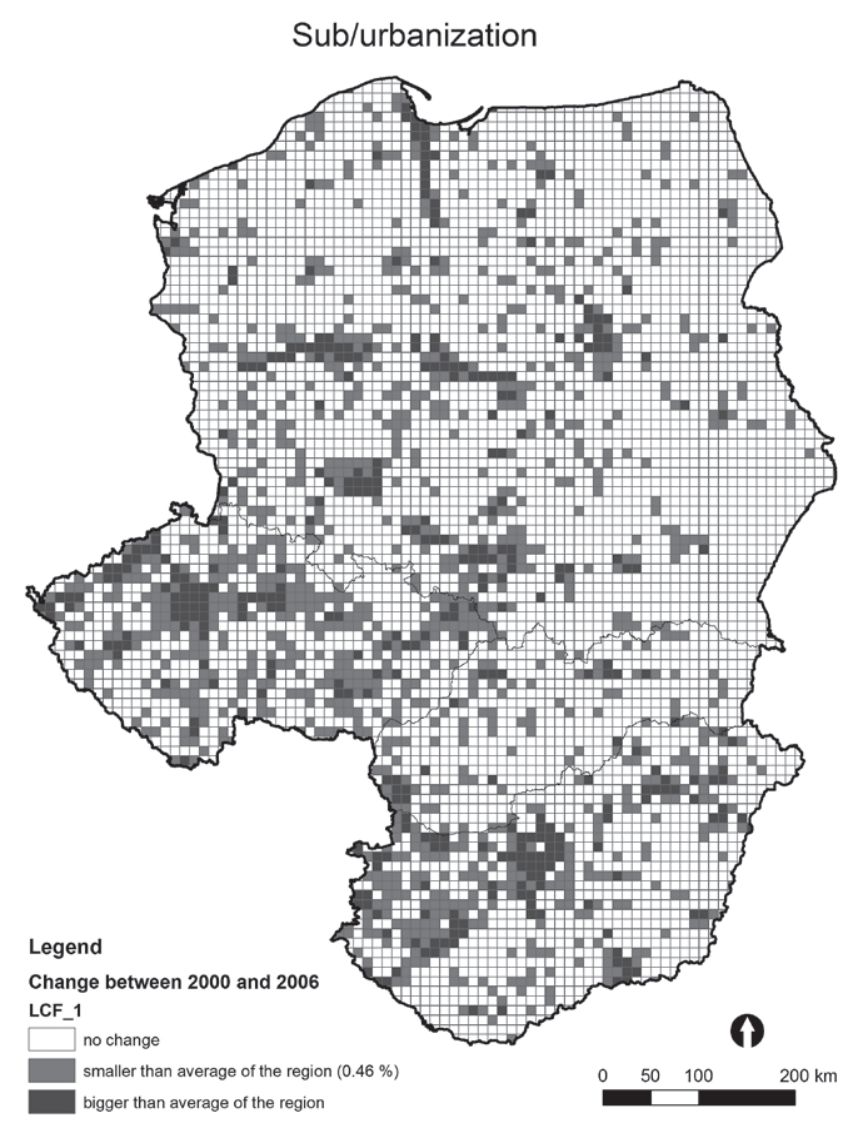

Fig. 3 Process of sub/urbanisation (2000-2006).

kolc. In Hungary, sub/urbanisation affected a total area of $191.15 \mathrm{~km}^{2}$ in the period $2000-2006$. The most distinct developments were the residential and commercial buildings in the outskirts of cities (Budapest, Debrecen, Miskolc, Szeged and in the west of Györ, Sopron and Szombathely) and expansion along transport networks, such the following motorways: M5 connecting Budapest and Szeged, M1 between Budapest and Györ and M7 connecting Budapest and Nagykanizsa.

Changes in land cover associated with sub/urbanisation affected an area of $59.10 \mathrm{~km}^{2}$ in Slovakia. The most significant development of built-up areas occurred in the western part in border areas, in particular in Bratislava, Nitra and Trnava, and also in Prešov, Košice, Poprad, Žilina, Trenčín, Banská Bystrica etc. In the period 2000-2006 the area affected by sub/urbanisation was $37.30 \mathrm{~km}^{2}$ and occurred mainly in the immediate zone of Bratislava, Žilina, Poprad and Trnava, and adjacent to some important routes.

\section{Intensification of agriculture (LCF 2)}

Intensification of agriculture affected a total area 1,466.90 $\mathrm{km}^{2}$ over the period 1990-2000. During the second period, the area was smaller $\left(717.19 \mathrm{~km}^{2}\right)$. In Hungary, the area affected by the intensification of agriculture was $768.87 \mathrm{~km}^{2}$, with the most signifiant changes occurring in fertile lowlands in the Szamos basin northeast of the city of Debrecen. Other regions affected were the 


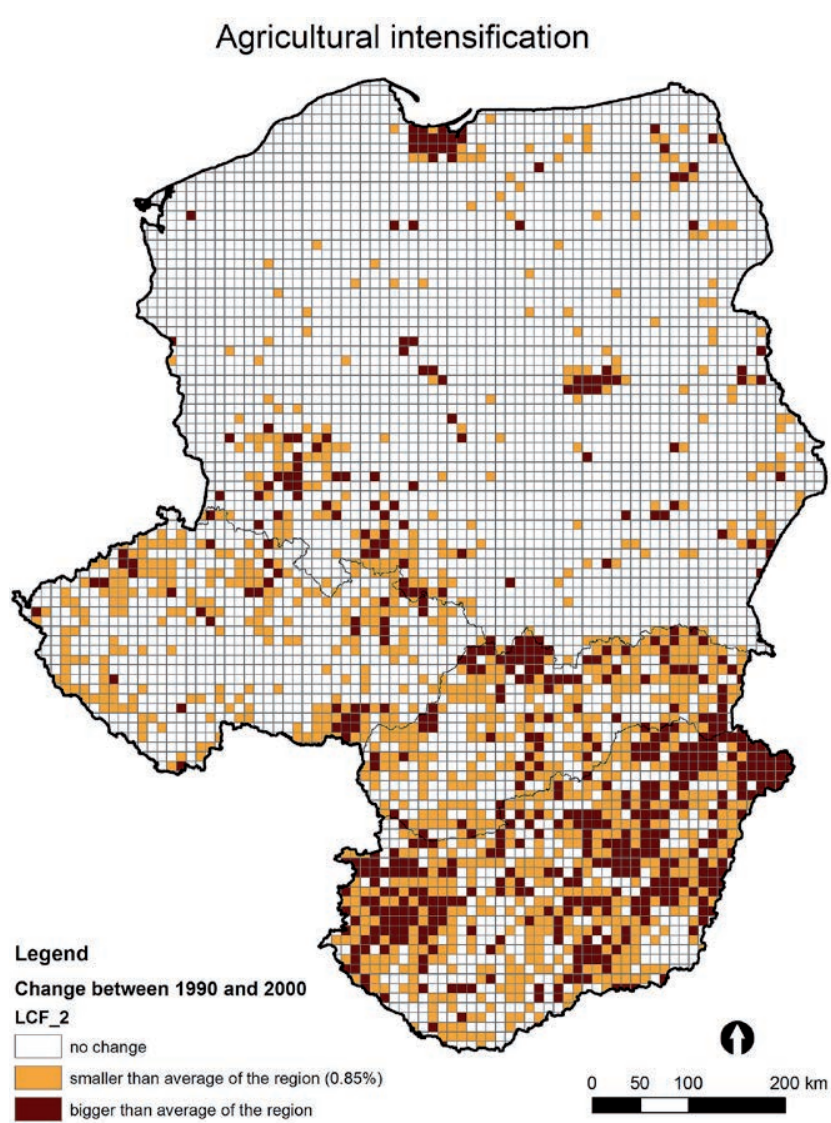

Fig. 4 Process of intensification of agriculture (1990-2000).

lowlands along the rivers Tisa and Körös, around Lake Balaton. During the second period, intensification of agriculture occurred mainly in lowlands in the Tisa and Szamos basins in the east of Hungary and in the Körös basin in the northeastern part of the Great Hungarian lowland.

In Poland it affected $314.45 \mathrm{~km}^{2}$, with the most significant changes occurring in northern Poland in the region of Visla bay, on the eastern edge of the Pomořanská lake platform at the mouth of the river Visla in Gdaňsk bay and the eastern part of the Mazurska lake platform, in large areas in the Mazovská lowlands in the Wisla basin, Slezská lowlands and edge of the Velkopolská lowland. In comparison with the previous period, between 2000 and 2006 there was a large decrease in area affected $\left(132.59 \mathrm{~km}^{2}\right)$. This process continued in Central Poland, in particular, in the fertile lowlands in the Wisla basin in region of the Mazovska lake platform and on the eastern edge of the Velkopolská lowland. The most significant changes in land cover occured in northern Poland at mouth of Wisla on the Baltic Sea. In other regions, the area affected decreased.

In Slovakia, the area affected was $242.71 \mathrm{~km}^{2}$, with the main areas affected in the sub-mountainous regions of Javorníky, Oravské Beskydy and Malá Fatra. Other areas where there were increases were in the Východoslovenská lowlands, foothills of Vihorlatské vrchy, highlands of Laborecká and Ondavská vrchovina and regions

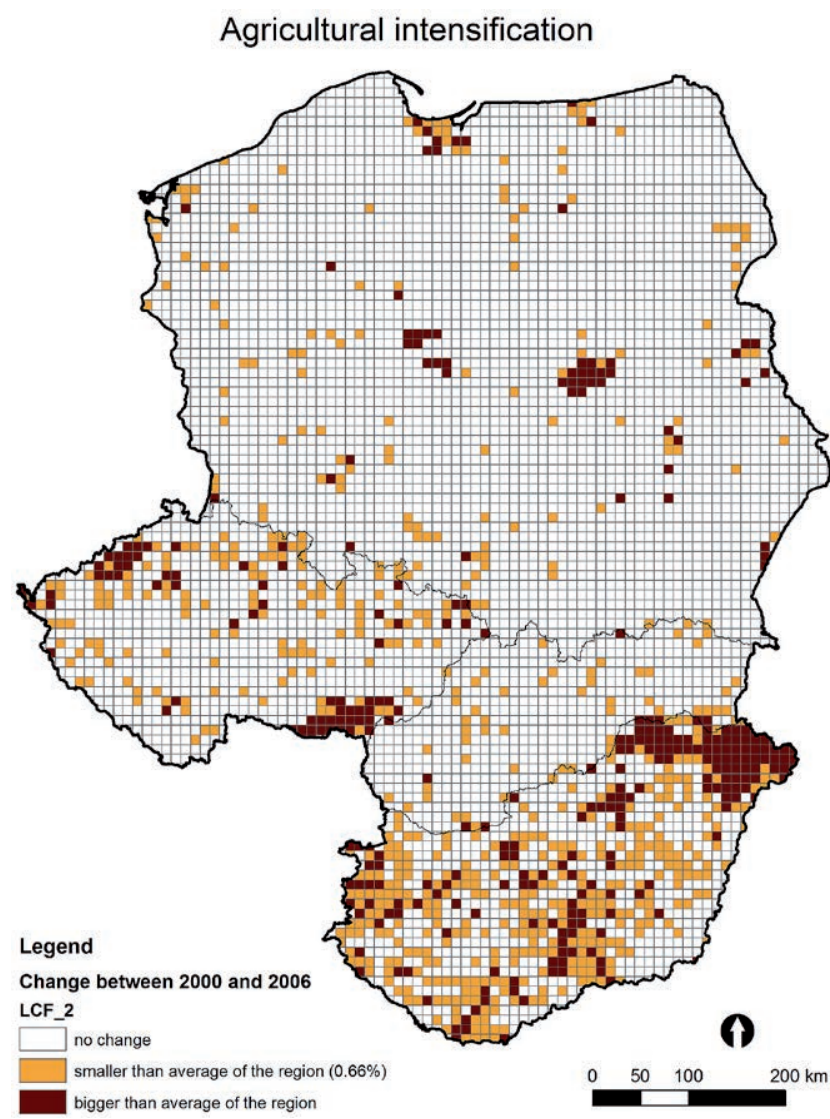

Fig. 5 Process of intensification of agriculture (2000-2006).

around Spiš. Between 2000 and 2006, the area affected decreased to only $10 \%$ of the value in previous period $\left(24.64 \mathrm{~km}^{2}\right)$, with the changes recorded only in several small regions in Podunajská lowlands in the surrounding of Trnava and in the Východoslovenská lowlands.

The smallest area affected was recorded in the Czech Republic $\left(140.84 \mathrm{~km}^{2}\right)$, with the level of intensification depending on natural conditions. It was concentrated in the warmest regions of Dyjskosvratecký úval and Dolnomoravský úval, and in lowlands in the region of Poohří and Polabí (lowlands of Žatecko, Lounsko), but significantly also in the colder foothills of the Šumava and Nízký Jeseník. Between 2000 and 2006, the area affected increased to $152.17 \mathrm{~km}^{2}$, with he most significant increases in the warmest regions of fertile lowlands. As during the previous period, this process continued in the same regions and extended to regions in the Svratka basin, Litoměřicko and highlands in the České středohoří. In the regions of Chebská and Sokolovská pánev the changes were associated with the recultivation of former mining areas.

\section{Extensification of agriculture (LCF 3)}

While between 1990 and 2000 the area land subjected to this type of change in land use reached $4,138.10 \mathrm{~km}^{2}$ and in the second period was $927.82 \mathrm{~km}^{2}$. Generally, there was an overall decline in the area subjected to this type of land change in the whole of Central Europe. In 


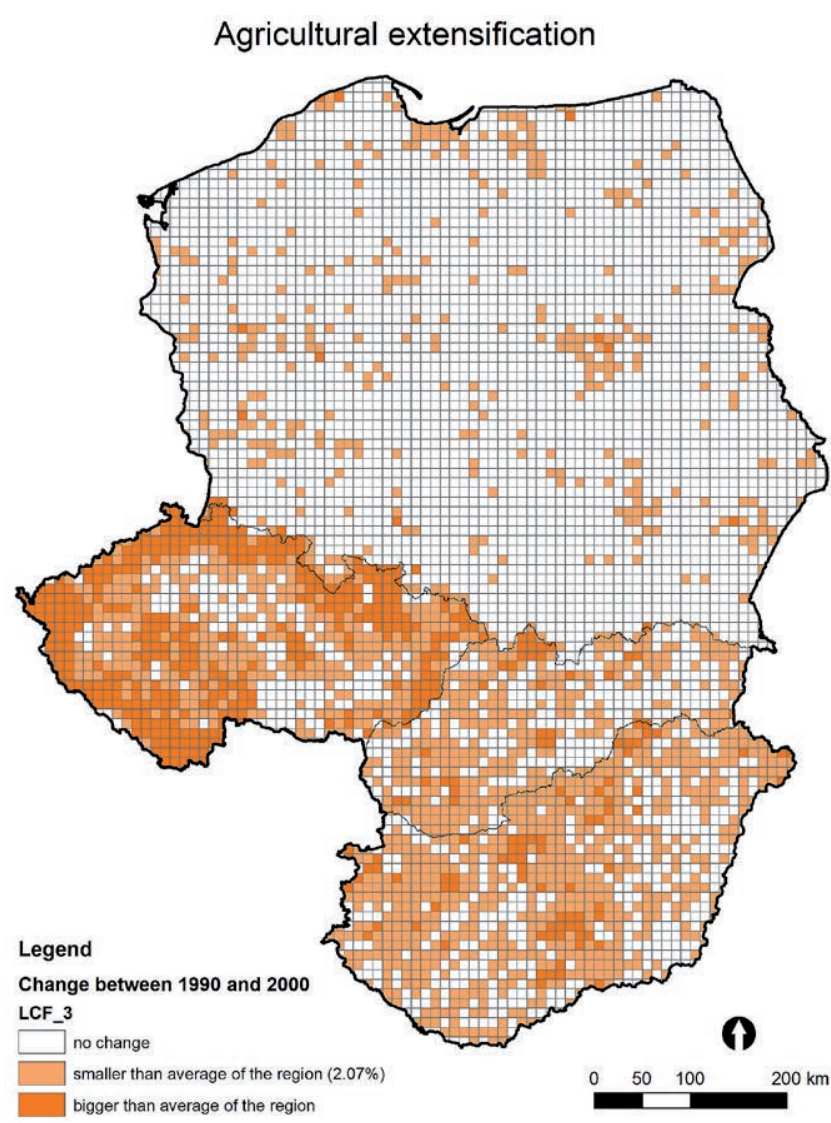

Fig. 6 Process of extensification of agriculture (1990-2000).

the previous period, large parts of the Czech Republic, Hungary and Slovakia were subjected to this type of land use. In the period 2000-2006, there were several separate centers of extensive agriculture. This was particularly common in the Czech Republic. During the first period, it covered an area of $2,936.44 \mathrm{~km}^{2}$. The most significant changes in landscape associated with extensification of agriculture were mainly recorded in the mountains and foothills in border areas in the region of Novohradské hory, foothills of Šumava, Doupovské hory, Slavkovský les, Lužické hory and České stř̌edohoří, and to a lesser extent in the region of Králický Sněžník, Kladská kotlina, Hanušovická vrchovina and the mountains of Nízký and Hrubý Jeseník, highlands of Javořická vrchovina, Ždárské vrchy and Jihlavské vrchy. In comparison with the previous period, there was a significant decline in both the area $\left(643.89 \mathrm{~km}^{2}\right)$ and the percentage of the area of the country from $3.72 \%(1990-2000)$ to $0.82 \%$ in the period 2000-2006. Landscape changes connected with extensification of agriculture were significant in regions mentioned above and the regions Smrčiny, Karlovarská vrchovina, Orlické hory, Broumovská vrchovina and Bílé Karpaty. In comparison with the Czech Republic, a significantly smaller area was affected by extensification of agriculture in other countries assessed. In Hungary, the area affected was $679.89 \mathrm{~km}^{2}$ and mainly occurred in the Matra and Bukovské hory regions and in part of the Tisa basin. Between 2000 and 2006, the area affected was only
Agricultural extensification

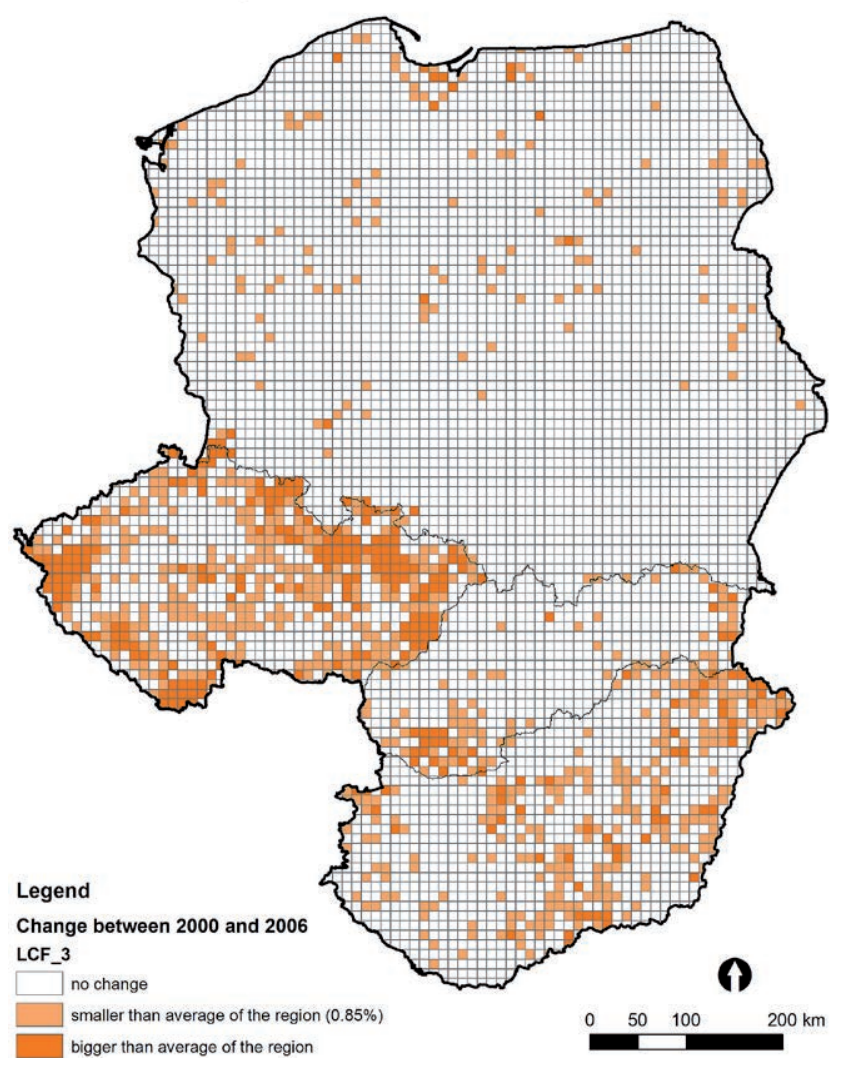

Fig. 7 Process of extensification of agriculture (2000-2006).

$158.73 \mathrm{~km}^{2}$. The process of extensification of agriculture was concentrated mainly in the border area with Romania, lowlands in the Tisa and Szamos basins and the whole area of lowlands in the basin of the Danube River. There were also land cover changes at a few separate localities on the Great Hungarian Plain.

In Slovakia, the area affected by the extensification of agriculture was only $295.56 \mathrm{~km}^{2}$ and mainly occurred in the region of Oravské Beskydy and Oravská Magura. The intensity was comparable with the situation in the region Nízký Jeseník, but the area affected was smaller. The total area affected in the period 2000-2006 was $60.87 \mathrm{~km}^{2}$. This type of landscape change occurred mainly at two locations but with a greater intensity. The first region consists of a belt stretching from Laborecká and Ondavská vrchovina through Vihorlatské vrchy to the north of the lowlands on the border with Ukraine. The second area was the lowlands in the Dudváh basin. In the Levočské hills this type of agriculture ceased.

The area of extensification of agriculture reached $226.20 \mathrm{~km}^{2}$ in Poland. This analysis indicaters that in Poland the affect of the extensification of agriculture was marginal with minimal scope and intensity. In the period 2000-2006, the area of extensification of agriculture was $64.32 \mathrm{~km}^{2}$ in Poland and the land cover changes were more scattered. Numerous relatively large areas were located in the lowlands. At higher altitudes, it occurred only in border regions, highlands of Frýdlantská pahorkatina, 


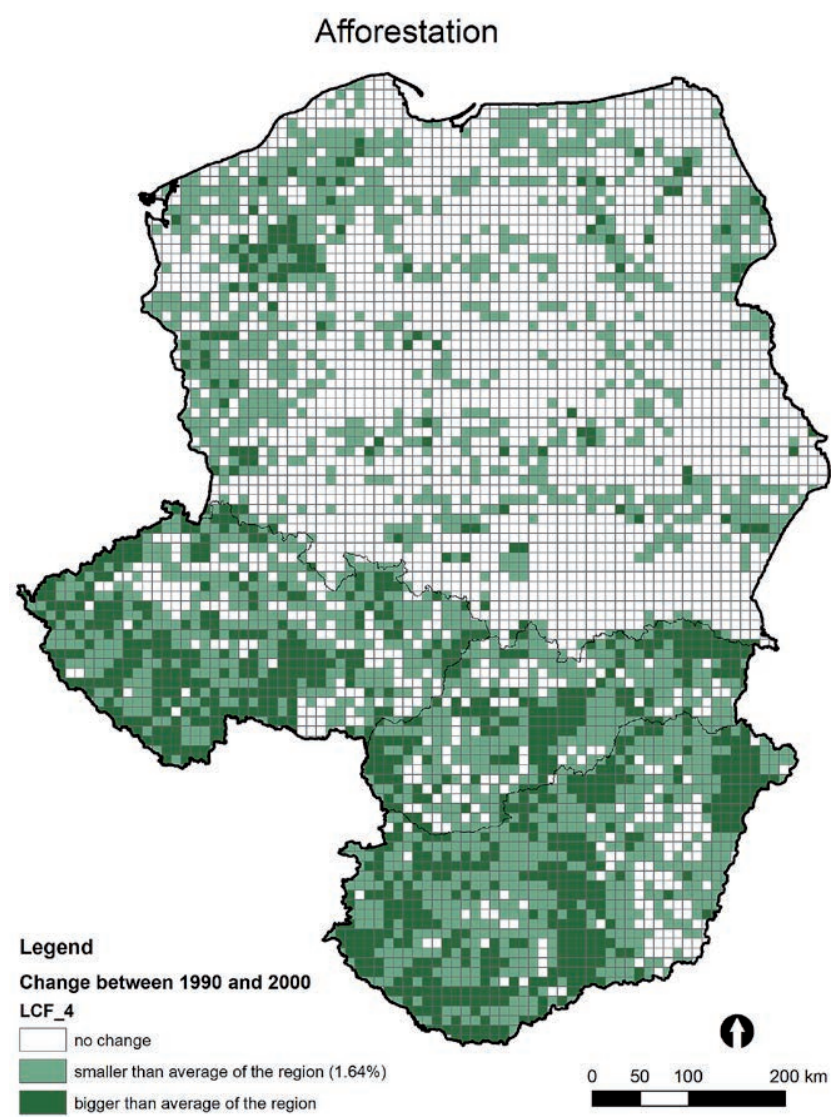

Fig. 8 Process of afforestation (1990-2000).

Zlatohorská pahorkatina, Žulovská pahorkatina or lowlands of Vidnavská. Significant changes in landscape due to extensification of agriculture occurred in the north of Poland in region of the mouth of the river in Gdansk Bay.

\section{Afforestation (LCF 4)}

The results of this analysis indicates that the area of afforestation was biggest $\left(1,709.27 \mathrm{~km}^{2}\right)$ in Hungary between 1990 and 2000, mainly in two regions, northeastern region near the border with Romania and in central Hungary in the western part of the Great Hungarian Plain along the rivers Danube and Tisa and almost the entire western third of the country. Significant afforestation occurred also in the northern mountains (Bakoňský les, Vértes, Cserhát, Mátra, Bukovské hory). Between 2000 a 2006 , the area of afforestation was $1,100.44 \mathrm{~km}^{2}$. Although there was a decline in the area of afforestation, the percentage of the area affected by all the processes studied almost did not change. This means that the relative area of changes in landscape associated with the possitive process of afforestation increased at the expense of other process. Afforestation continued in the same regions as in the first period. Only the region between mountains Bakoňský les and Bukovské hory was not so important in terms of afforestation.

A smaller area of afforestation was recorded in the Czech Republic, where it was $1,289.11 \mathrm{~km}^{2}$ and occurred

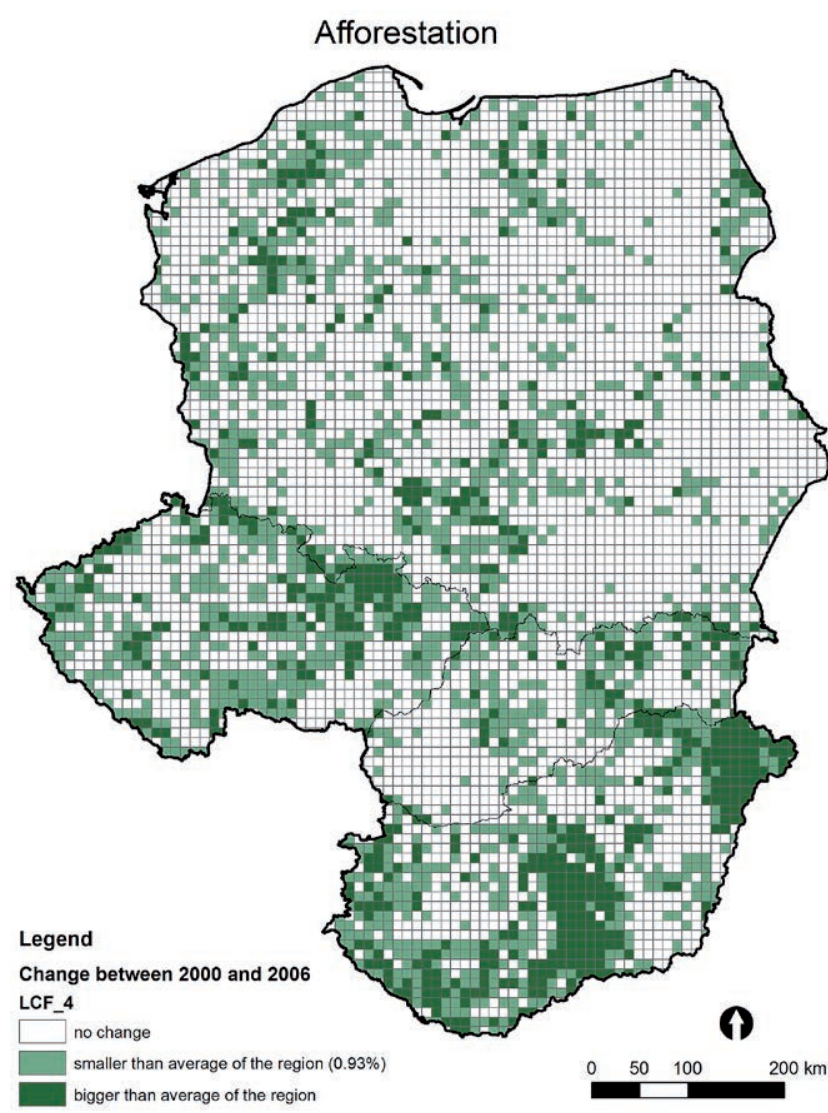

Fig. 9 Process of afforestation (2000-2006).

mainly in the border regions in the mountains of Jizerské and Lužické hory, Krušné hory, Český les and in the region of Šumava and foothills of Šumava. There was also significant afforestation in the region of Rychlebské hory, Nízký and Hrubý Jeseník, Moravskoslezské Beskydy and Javorníky. Afforestation was also associated with recultivation of former mining areas in Podkrušnohoři and Ostravsko regions. Another distinct process of afforestation also occurred in former military training areas (Císařský les, Doupov, Libavá, Ralsko, Boletice). Between 2000 and 2006, the area of afforestation $\left(432.21 \mathrm{~km}^{2}\right)$ was significantly smaller than in the previous period. Afforestation continued in some border areas, mountains of Nízký and Hrubý Jeseník, Moravskoslezské Beskydy, Český les, Šumava and foothills of Šumava, Krkonoše and Jizerské hory. Significant afforestation occurred in a belt stretching from the mountains and foothills of Orlické hory, through the highlands of Kladská kotlina, Hanušovická vrchovina and Zábřežská vrchovina to the lowlands of Hornomoravský úval and Vyškovská brána. In the highlands of Brdska vrchovina and Ralsko the afforestation continued especially in connection with the decline in activities in the military training areas.

In Poland, the area of afforestation was $793.15 \mathrm{~km}^{2}$. The largest area of afforestation was on the western part of Pomořanská lake platform and Velkopolská lake platform, Krajenská jezerní oblast and in the Masovian lowlands and wetlands in the south of the Masurian 
Lake District lowlands. Between 2000 and 2006 the area of afforestation reached $606.32 \mathrm{~km}^{2}$ and continued on the western part of the Pomořanská lake platform with a continuous belt stretching from the Silesian border through the highlands of Malopolská vrchovina to Lublinská vrchovina.

In Slovakia afforestation affected an area of $772.92 \mathrm{~km}^{2}$, mainly in the eastern part of the country (highlands of Laborecká vrchovina, Ondavská vrchovina and Vihorlatské vrchy) and to a lesser extent in the western part of Slovenské rudohorie and regions of Štiavnické vrchy, Tríbeč, Vtáčnik and Strážovské vrchy. In the second period the area affected by afforestation was smaller $\left(128.40 \mathrm{~km}^{2}\right)$, with the largest area in the region of Laborecká and Ondavská vrchovina, Vihorlatské vrchy and Bukovské vrchy. Significant afforestation also occurred in the region of Spišská Magura.

\section{Deforestation (LCF5)}

During the period 1990-2000, there was a decline in the area of forest by an area of deforestation of $2,769.4 \mathrm{~km}^{2}$. In the second period (2000-2006), deforestation affected almost the same area as afforestation. The total area of deforestation was $2,170.51 \mathrm{~km}^{2}$. In comparison with the previous period, deforestation decreased by about one quarter (22\%). Important indicator is the relative percentage of the area of all the landscape changes in Central Europe, which increased in case of deforestation from $20.16 \%$ in the period $1990-2000$ to $31.95 \%$ in $2000-2006$.

The total area of deforestation in Poland was $874.12 \mathrm{~km}^{2}$ and was mainly occurred in southern Poland on the eastern edge of the Silesian Lowland and the Velkopolská lowland and to a lesser extent in the Odra basin, surroundings of Wroclaw and in the highlands of Malopolská vrchovina, Lublinská vrchovina and lowlands on the eastern and western parts of Velkopolská lake platform. In Poland, there was clear shift in the center of deforestation from high altitudes to the lowlands in the second period. The area was $719.81 \mathrm{~km}^{2}$ and mainly occurred in the eastern regions of Velkopolská and Slezská lowland and Mazurská jezera.

A smaller area of deforestation was recorded in Hungary $\left(788.87 \mathrm{~km}^{2}\right)$. Suprisingly significant deforestation occurred in areas where afforestation occurred. However, deforestation affected a much smaller area. Most deforestation occurred in eastern Hungary near the border with Romania and to lesser extent in the western part of Great Hungarian Plain, border areas in the west and in the region of Malá uherská lowland, Bakoňský les and highlands of Bukovské hory and Mátra. In the second period (2000-2006) area of deforestation was similar (difference of $28 \mathrm{~km}^{2}$ ) $760.65 \mathrm{~km}^{2}$. Deforestation was characterized by a similar spatial extension as in the previous

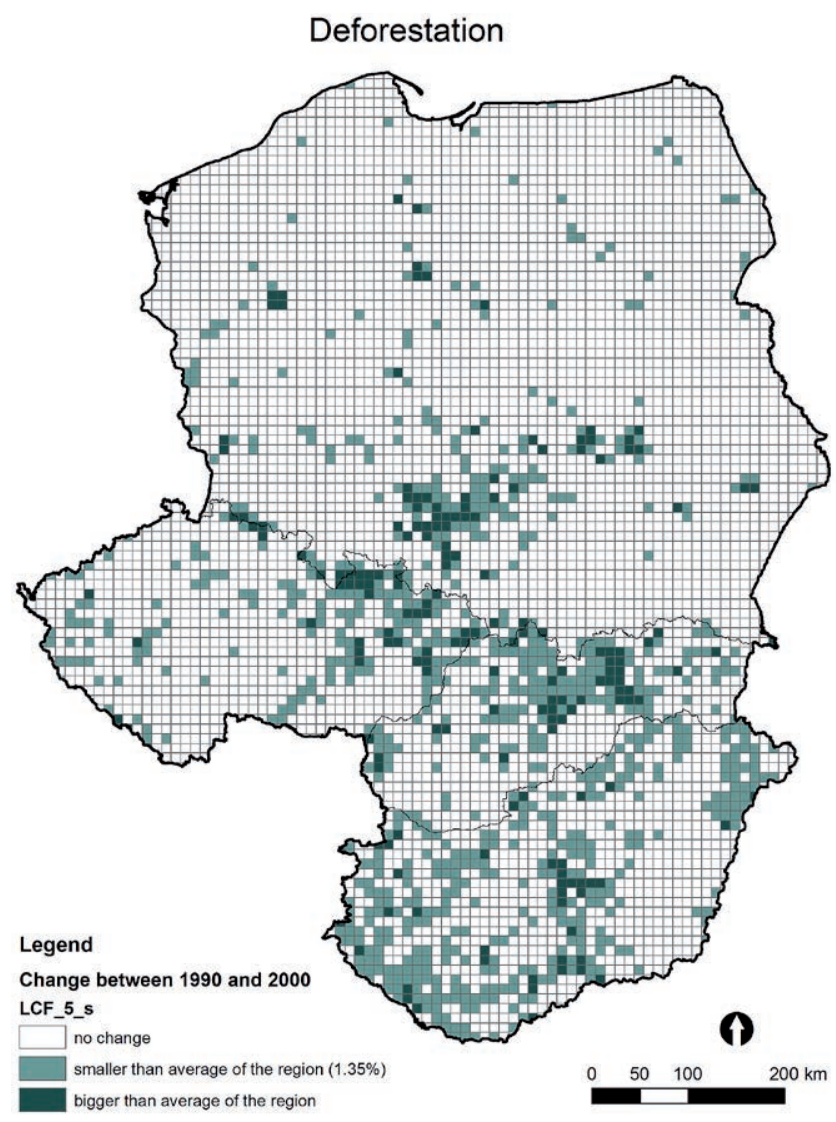

Fig. 10 Process of deforestation (1990-2000).

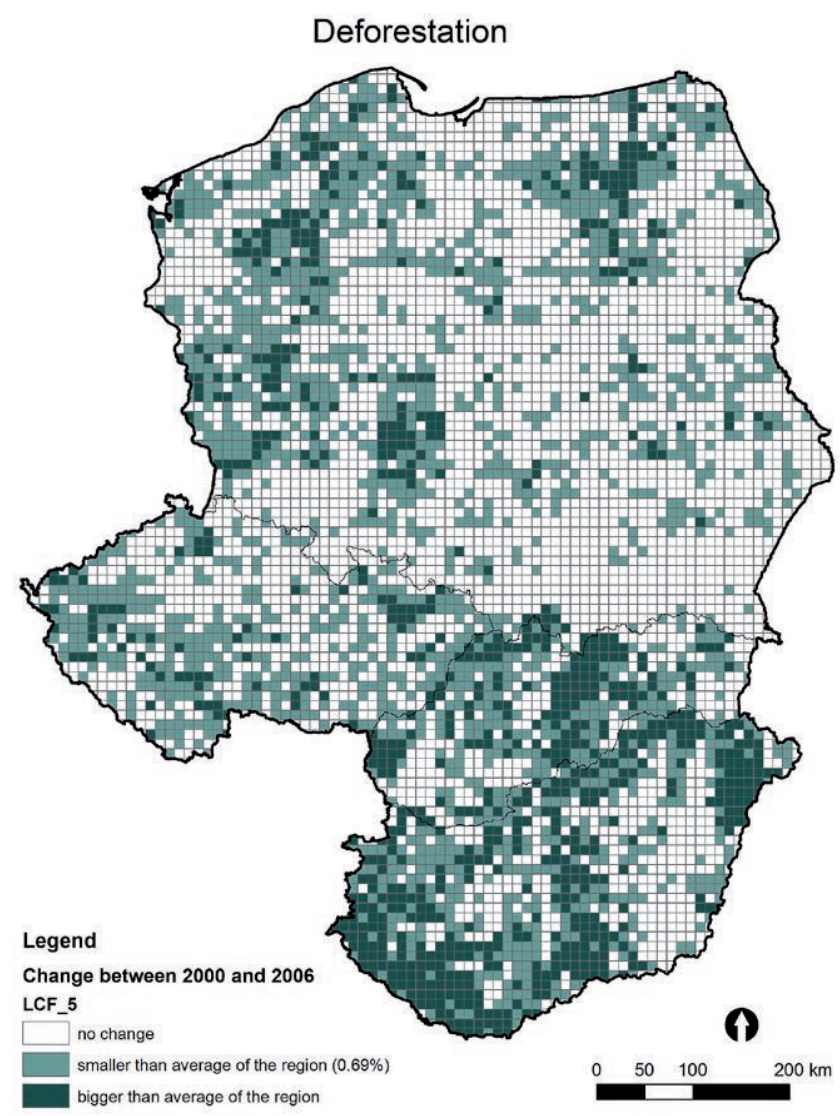

Fig. 11 Process of deforestation (2000-2006). 
period and increase in intensity. The most signifiant increase was in the western border area and Drava basin in the northern part of the Malá uherská lowlands. A further increase in the extent occured in the lowlands in the Danube and Tisa basins. Deforestation continued in the Bakoňský les, Mátra, Bukové hory and eastern Hungary.

The area of deforested landscape in Slovakia was $557.99 \mathrm{~km}^{2}$, which mainly occurred in the central part of Slovakia in the region of Levočské vrchy, Čergov, Spiš, Nízké Tatry, Slovenské rudohorie, Orava and Velká and Malá Fatra. In the second period (2000-2006) a further area of $49.36 \mathrm{~km}^{2}$ was deforested. The process of deforestation continued in the region of Spišská Magura and Levočské vrchy. Significant deforestation also occured in large areas in the region of Nízké and Vysoké Tatry. Extensive deforestation was associated with the gale (storm) and subsequent tree felling in 2004. Other areas of deforestation were identified in the region of Oravské Beskydy, Javorníky, Bílé Karpaty, Laborecká vrchovina and in the lowlands of Morava River.

In the Czech Republic the area of the deforestation reached $548.39 \mathrm{~km}^{2}$ most of which was in the region of Krkonoše, Doupovské hory, Šumava, Krušné hory and Brdská vrchovina or Polabská lowland. More significant deforestation occurred in northern Moravia in the region of Králický Sněžník, Kladská kotlina, Hrubý a Nízký Jeseník, Moravskoslezské Beskydy, Brněnská vrchovina and on the eastern edge of Českomoravská vrchovina. In the second period (2000-2006), the area of deforestation was the lowest in the Czech Republic with a total area of $198.69 \mathrm{~km}^{2}$.

\section{Artificial water bodies (LCF 6)}

The last of the land cover changes included in the analysis was artificial water bodies. In comparison with other processess, it affected the landscape only marginally. Nevertheless, it had a significant effect on the landscape. The total area so affected in Central Europe in the period 1990-2000 was $218 \mathrm{~km}^{2}$ and between 2000 and 2006 it was only $83.0 \mathrm{~km}^{2}$ (Appendix 2).

In the period 1990-2000 the most significant area of construction of artificial water bodies occurred in Poland where reached a total area $86.06 \mathrm{~km}^{2}$, mainly in the form of extensions to numerous lake basins, which occurred throughout the whole area of this country. Between 2000 and 2006 the area affected was $45.04 \mathrm{~km}^{2}$ and involved only the construction of new water bodies, not watercourses and was concentrated in several centers in southern parts of Poland, mainly in the eastern part of the Slezská lowland (upper reaches of the Odra River).

Only a slightly smaller area was affected in Slovakia $\left(67.03 \mathrm{~km}^{2}\right)$ and that was mainly in the region of the Gabčíkovo dam on the river Danube, with smaller areas in the region of Orava in the north of Slovakia and signif-

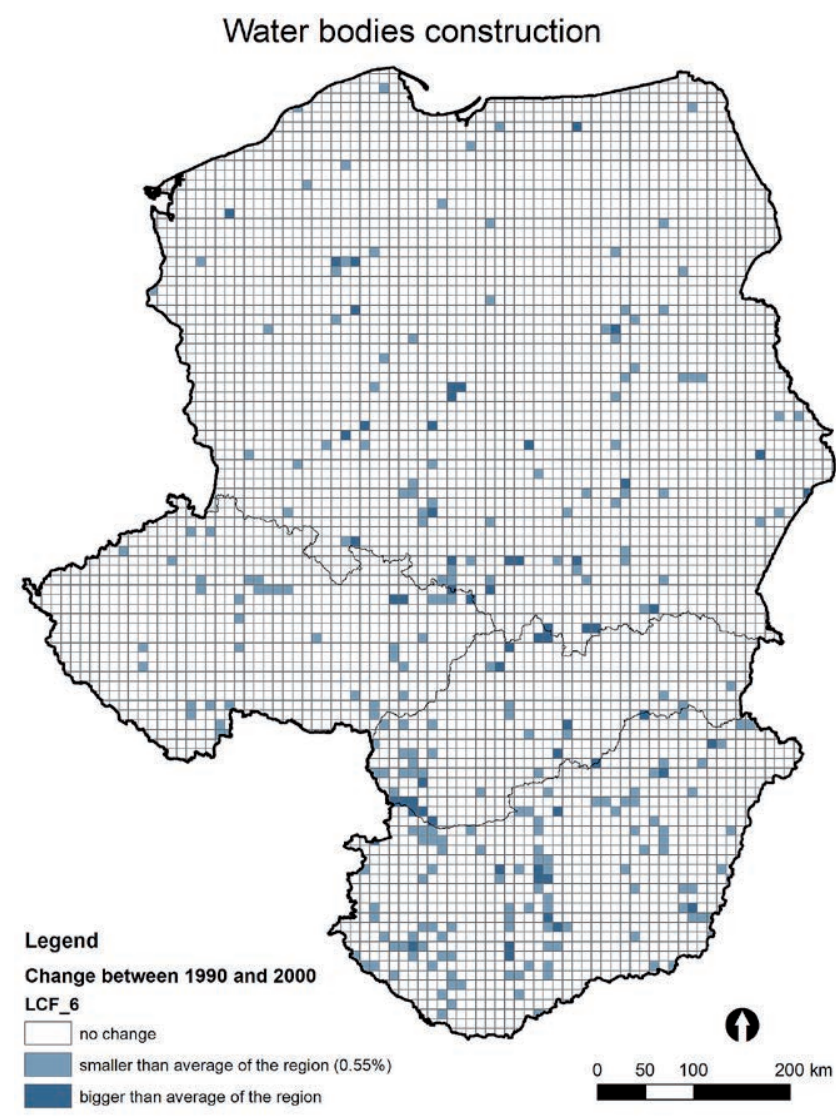

Fig. 12 Water body construction (1990-2000).

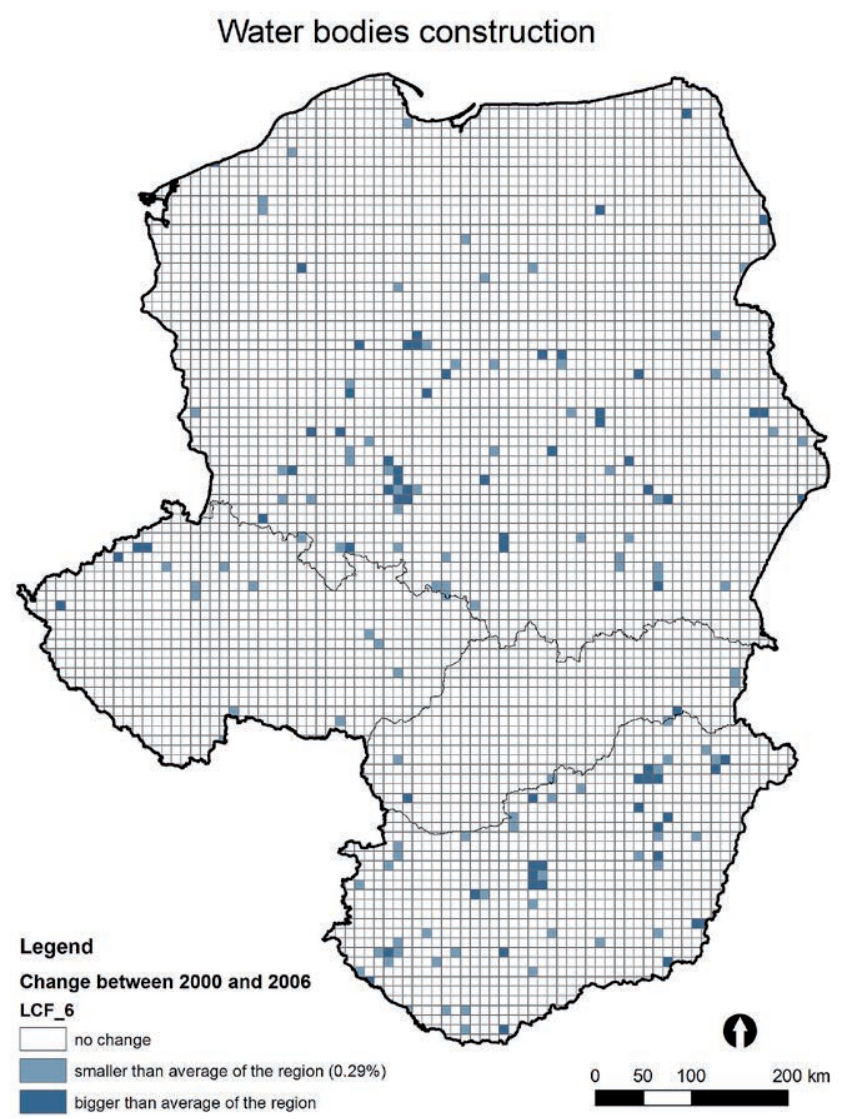

Fig. 13 Water body construction (2000-2006). 
icant areas also in Central Slovakia. In the second period (2000-2006), it affected only $1.51 \mathrm{~km}^{2}$ and in comparison with previous period the decrease was very rapid. There were only few small areas in the western and eastern parts of Slovakia.

The area affected in Hungary was even less, $46.18 \mathrm{~km}^{2}$ (1990-2000) and mainly occurred in the lowlands throughout the country but most significantly in the Danube and Tisa basins in central Hungary and in the southwestern lowlands in region of the Malá uherská lowlands, with few localituies in the east. Between 2000 and 2006, there was a decrease in the extent of this change in landscape with the construction occurring mainly in the central part (lowlands of Danube River) and northeastern part (lowlands of Tisa River) of Hungary.

In the Czech Republic, the area affected was the lowest. In the period 1990-2000, the total area of $18.74 \mathrm{~km}^{2}$ was mainly associated with the construction of water bodies in the north of Moravia. In 1997, the Slezská Harta dam was finished and started operating and numerus ponds were constructed in the south of Bohemia and in Central Bohemia in lowlands of the Labe River. A significantly lower area of $5.70 \mathrm{~km}^{2}$ was affected in the second period as very few water bodies were constructed and only in small areas in the region of Mostecko and Sokolovsko and associated there with the recultivation a mining area. Other areas affected were in the lowlands of Morava
River and in the region of Jindřichův Hradec and Mikulov.

\section{Types of landscape (cluster analysis)}

Based on the cluster analysis of both periods, 19902000 and 2000-2006, the following five types of landscape itemised below were identified. Their spatial extent in Central Europe is shown on the maps included in Figs. 14 and 15. In Appendix 3-4 there are graphs with the average values of the percentages of the land cover changes mentioned in the five clusters.

\section{Types of landscape in Central Europe (1990-2000) Type of landscape 1}

In cluster 1 are the regions where sub/urbanisation and construction of water bodies were the most significant. Based on results of the cluster analysis this cluster includes the most important causes of changes in land cover, with sub/urbanisation more important than the construction of water bodies. In terms of natural conditions, the first type of landscape occurs in the regions of big cities and in their outskirts and the second in lowland floodplains of big rivers.

\section{Type of landscape 2}

Cluster 2 includes extensification of agriculture. While the average value for Central Europe was $2.07 \%$ the clus-

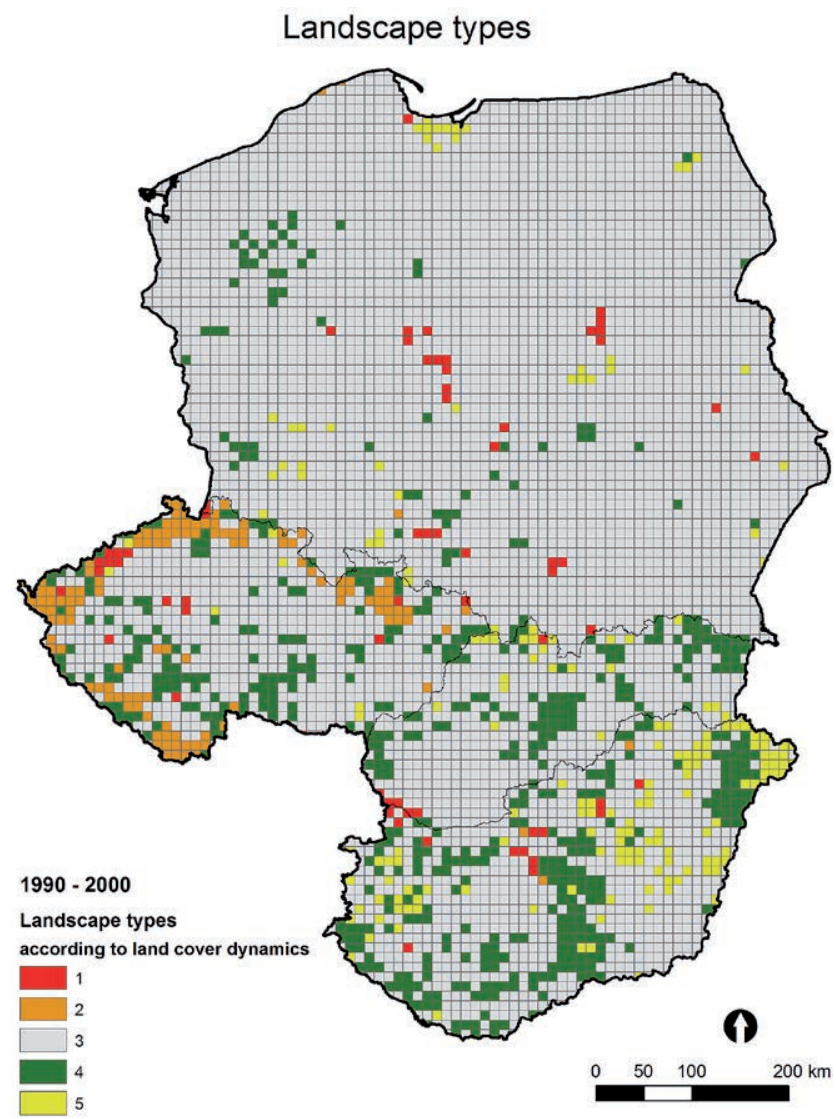

Fig. 14 Types of landscape (1990-2000).

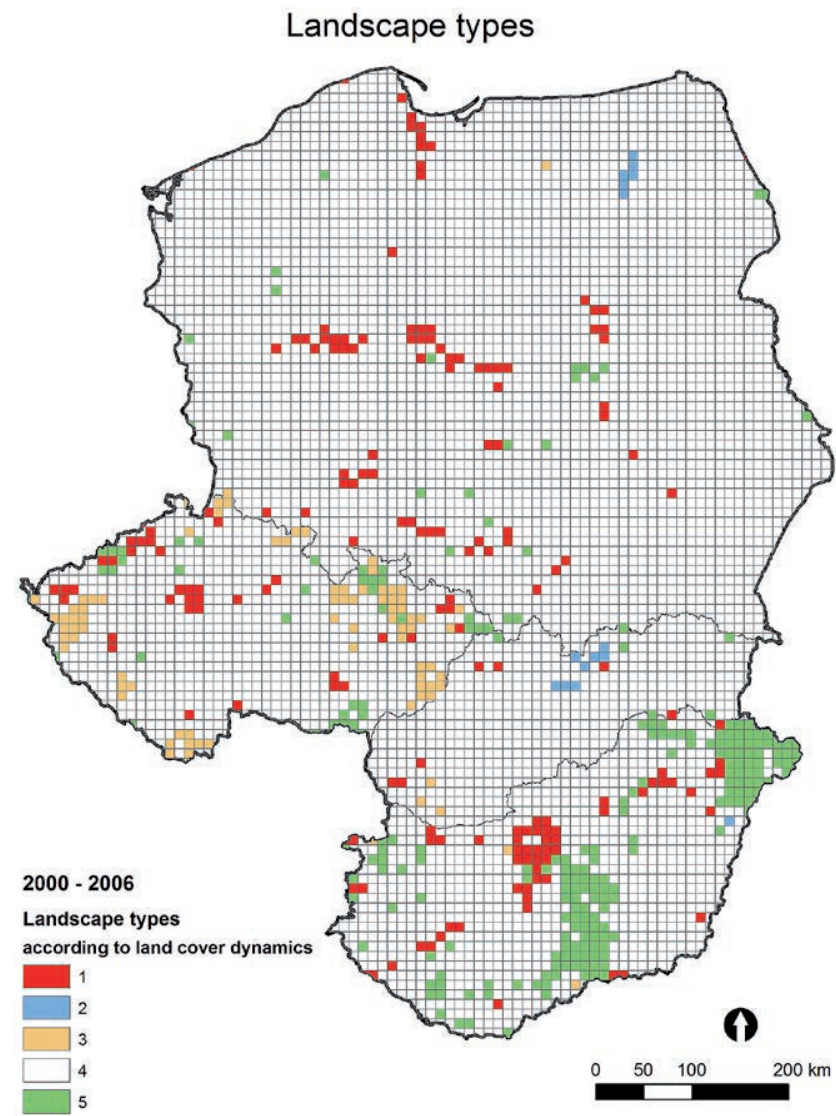

Fig. 15 Types of landscape (2000-2006). 
ter mean value was $14.78 \%$. This extraordinary value far above the average for the region assessed was not noted in any other cluster. Throughout the period 1990-2006 the extensification of agriculture was a phenomenon specific to the landscape of the Czech Republic. This kind of land cover changes did not occur anywhere else in Europe to the same extent as in the Czech Republic. The reasons are outlined in the previous chapter of this paper.

\section{Type of landscape 3}

Between 1990 and 2000 cluster 3 includes those regions where any kind of change in land cover occured. There were no landscape changes that were crucial for the formation of the landscape mosaic. This type of landscape is characterized by the fact that there were no significant changes in land cover. As expected, this type of landscape occupied the largest area in Central Europe in the period 1990-2000.

\section{Type of landscape 4}

Cluster 4 includes landscapes dominated by two contradictory changes in land cover, the massive afforestation associated with expanding forest stands in the landscape and deforestation in a significant part of this type of landscape.

\section{Type of landscape 5}

This type of landscape is significantly affected by the intensification of agriculture. The main occurence of this kind of change in land cover occurred mostly in the fertile lowlands and at lower altitudes in foothills.

\section{Types of landscape in region of Central Europe (2000-2006)}

Type of landscape 1

Based on results of the cluster analysis cluster 1 includes landscape in which sub/urbanisation is dominant and the construction of water bodies less so as it was not decisive for this type of landscape. Water bodies were constructed only in a few regions in Central Europe.

\section{Type of landscape 2}

Cluster 2 includes landscapes affected mainly by deforestation. In terms of effect of this on the landscape, other changes in land cover had less of an affect the landscape and no significant effect on the landscape mosaic. The type of landscape associated with deforestation occured only in two not very large regions in Slovakia and Poland (see Fig. 15).

\section{Type of landscape 3}

In case of cluster 3 the dominant change in land cover was associated with the extensification of agriculture. From the spatial distribution of extensification of agriculture it is clear that this type of landscape occurred in the Czech Republic and nowhere else. Between 2000 and 2006 the same situation prevailed as in 1990-2000.
This type of landscape was concentrated mainly in the uplands in the border region.

\section{Type of landscape 4}

Between 2000 and 2006, cluster 4 included landscapes where none of the changes in land cover assessed occured. As in the previous period, this type of landscape was the most common in Central Europe.

\section{Type of landscape 5}

Cluster 5 includes two types of changes in landscape, the intensification of agriculture associated with the expansion of arable land and afforestation. In some regions, this type of landscape was made up of mainly abandoned and less fertile soils left to spontaneous natural succesion. In other regions, the intensification of agriculture was more pronounced and resulted in changes in land cover.

\section{Discussion}

As the results of the analysis show there have been very specific changes in land cover in Central Europe. Changes in landscape occured and are still occurring in in relatively different context than in the rest of Europe. Nevertheless, it is possible to identify similar trends. While the paper by Feranec et al. (2010) shows that the European landscape was significantly shaped by the six basic processes of changes in land cover it is clear that some processes were more effective and widespread while others were not so significant. Some changes in land cover were not as extensive as others were, or occurred only in some regions, or some countries. A typical example is the extensification of agriculture, which occurred solely in the Czech Republic during both periods, 1990-2000 and 2000-2006.

The expectation is that the six basic changes in land cover described for the whole Europe also occurred in Central Europe and shaped six corresponding types of landscape, within each of which there would be one dominant process resulting in change in land cover (sub/urbanisation, intensification of agriculture, extensification of agriculture, afforestation, deforestation and construction of water bodies). The actual situation is quite different.

Based on the cluster analysis five types of landscape were identified in each of the periods. One type of landscape is characterized by none of the fundamental processes that result in changes in land cover applying to the extent that they could be considered as determining this type of landscape. The remaining four types of landscape include one dominant or a combination of processes resulting in change in land cover. Based on the results of the cluster analysis it is clear that landscapes were primarily formed by extensification of agriculture and afforestation, intensification of agriculture, sub/urbanisation and deforestation in period 1990-2000. In period 2000-2006, 
the landscapes were primarily formed by deforestation and to a lesser extent by extensification of agriculture, afforestation, intensification of agriculture and sub/urbanisation. From results of this analysis it is also evident that the construction of water bodies completely ceased to be important in shaping the landscape. In comparison with other processes resulting in changes in land cover it had only a marginal effect and therefore was not decisive in forming any of the given types of landscape. While Feranec et al. (2010) report that the area used for constructing water bodies increased by more then $50 \mathrm{~km}^{2}$ only in Slovakia and Poland in period 1990-2000 (Feranec et al. 2010), the results of our analysis indicates that the value was almost the same in Hungary (more than $46 \mathrm{~km}^{2}$ ).

From the results it is also evident that the changes associated with extensification of agriculture resulted in a unique type of transformation in the landscape, which occurred exclusively in the Czech Republic. Similarly, Feranec et al. (2010) highlight the leading position of the Czech Republic in the list of European countries based on the area subject to an extensification of agriculture. According to Feranec et al. (2010), the area was $2,961.15 \mathrm{~km}^{2}$ in period 1990-2000, which is only slightly different from that identified by this analysis $\left(2,936.44 \mathrm{~km}^{2}\right)$. Between 1990 and 2000 extensification of agriculture occured in 3.5\% of the Czech Republic (Feranec et al. 2010). In the assessment of the changes landscape as part of the typology, the value was even higher $(3.72 \%$ of the territory of the Czech Republic in period 1990-2000). The situation in Poland was very different as it affected less than $0.1 \%$ of the country (Feranec et al. 2010). According to the results of this analysis, the percentage of extensification of agriculture in this country was $0.07 \%$ in the period $1990-2000$ and $0.02 \%$ between 2000 and 2006 .

\section{Conclusion}

The results of the analysis of changes in landscape are described in detail using maps (Figs. 2 - 15). Based on the database CORINE Land Cover, 305 types of changes in land cover were identified in the period 1990-2000 and 233 in the period 2000 and 2006. Subsequently, these changes in land cover were reclassified into six basic processes of changes in land cover that have resulted in most of the changes in landscape that have occurred in Central Europe. They are: Sub/urbanisation (LCF1), Intensification of agriculture (LCF2), Extensification of agriculture (LCF3), Afforestation (LCF4), Deforestation (LCF5) and Construction of water bodies (LCF6). The basic process used to identify the processes is that used by Feranec et al. (2010) (see Fig. 1). The spatial distribution of the processes resulting in changes in landscape was primarily determined by natural conditions and changes in land cover that occurred during the communist period.

While the Czech Republic was the country with the largest area of changes in land cover $\left(5,095 \mathrm{~km}^{2}\right.$ and $6.5 \%$ of the area of this country) in the period 1990-2000, during the second period 2000-2006 it was Hungary $\left(2,649 \mathrm{~km}^{2}\right.$ and $2.8 \%$ of the area of this country). During the period 1990-2006, the most significant change in land cover was associated with afforestation. In terms of the total area of afforestation it resulted in the largest change in land cover in Hungary $\left(2,809 \mathrm{~km}^{2}\right)$ and the Czech Republic $\left(1,721 \mathrm{~km}^{2}\right)$ between 1990 and 2006.

Landscape changes associated with extensification of agriculture resulted in the second and the third largest changes in land cover. It can be considered as a unique process in the formation of the landscape in the Czech Republic. Nowhere else in Europe did any other process have the same effect. The main reason was the need to repair the damage caused by the collectivization of the countryside. The most widespread type of change in land cover associated with the extensification of agriculture was the transformation of intensively used arable land into extensively used meadows and pastures. This type of change in landscape accounts for more than $81 \%$ of the total area of extensification of agriculture during the period 1990-2006. Primarily it was the abandonment of arable land in less fertile sloping sub-mountain regions and their subsequent grassing. Linked to this there was also the restoration of permanent landscape structures (hedgerows, woods, etc.) that significantly improve the ecological stability of a landscape.

Another significant change in land cover was that due to deforestation resulting in a distinct increase in the percentage of all other changes in land cover. In the majority of the cases ( $97.7 \%$ and $99.8 \%$, respectively) of deforestation was concentrated in regions with continuous forest, which at the end of each period were classified as class 324-Low forest vegetation. This indicates that immediately after deforestation the process of afforestation began.

Sub/urbanisation was the only one of the basic causes of changes in land cover that increased between the two periods assessed. Mainly it resulted from the transformation of rural areas into urbanized areas $(70 \%$ and $75 \%$, resperctively of all the changes in landscape associated with sub/urbanisation). The process of sub/urbanisation is defined as an increase in the numbers of two types of buildings. The first is called residential sub/ urbanisation and consists of satelite residential areas in the immediate surroundings of big cities (the so-called "urban sprawl"). During both periods it was the most significant type of sub/urbanisation $\left(292 \mathrm{~km}^{2}\right.$ between 1990-2006). The second type of sub/urbanisation is the expansion or building of new industrial and commercial buildings (logistic centers, warehouses, buildings for the trans-shipment of goods, etc.) close to mainly international roads.

Based on these results, five types of landscape were identified by using the cluster analysis in software Statistica 10. Always there was one type of landscape where none of the basic changes in land cover occurred. Be- 
tween 1990 and 2000, the first type of landscape in terms of area was characterized by a dominance suburbanisation and urbanisation and to a lesser extent by the construction of water bodies. In the next type of landscape in order of area was characterized by extensification of agriculture. The third type of landscape included those regions with no changes in land cover. The penultimate type of landscape was characterized by a combination of afforestation and deforestation. The last type of landscape identified intensification of agriculture as dominant. Spatial distribution of the different types is shown on the map in Fig. 14. In the period 2000-2006 the composition in terms of the types of landscape was different. Only the area of the first type of landscape was the same as in the previous period but the extent and construction of water bodies was less. The second type of landscape was that in which deforestation prevailed. In the third type of landscape, the most significant process was the extensification of agriculture. The fourth type included regions where no changes in land cover occurred. The last type of landscape was where there were two processes resulting in changes in the landscape: intensification of agriculture and afforestation.

\section{REFERENCES}

Büttner G, Kosztra B, Maucha G, Pataki R (2012) Implementation and achievements of CLC2006, European Environment Agency, Barcelona.

EEA Technical report No. 11/2006 (2006) Land accounts for Europe 1990-2000: Towards integrated land and ecosystem accounting. European Environment Agency, Copenhagen.

Feranec J, Š́ri M, Otahel J, Cebecauer T, Kolář J, Soukup T, Zdeňková D, Waszmuth J, Vajdea V, Vijdea A-M, Nitica C (2000) Inventory of major landscape changes in the Czech Republic, Hungary, Romania and Slovak Republic 1970s - 1990s. Int J Appl Earth Obs 2: 129-139.

Feranec J, Jaffrain G, Soukup T, Hazeu G (2010) Determining changes and flows in European landscapes 1990-2000 using CORINE Land Cover data. Appl Geogr 30: 19-35.

Romportl D, Chuman T, Lipský Z (2010) Landscape heterogeneity changes and their driving forces in the Czech Republic after 1990.

Appendix 1 Area of changes in land cover in Central Europe (1990-2000).

\begin{tabular}{|c|c|c|c|c|c|c|}
\hline & \multicolumn{3}{|c|}{ Czech Republic } & \multicolumn{3}{|c|}{ Slovakia } \\
\hline LCF & $\begin{array}{c}\text { Area of LCF } \\
{\left[\mathrm{km}^{2}\right]}\end{array}$ & $\begin{array}{l}\text { Percentage } \\
\text { of all LCF [\%] }\end{array}$ & $\begin{array}{l}\text { Percentage of } \\
\text { the country* [\%] }\end{array}$ & $\begin{array}{c}\text { Area of LCF } \\
{\left[\mathbf{k m}^{2}\right]}\end{array}$ & $\begin{array}{c}\text { Percentage of } \\
\text { all LCF [\%] }\end{array}$ & $\begin{array}{l}\text { Percentage of } \\
\text { the country* [\%] }\end{array}$ \\
\hline Sub/urbanisation & 161.64 & 3.17 & 0.205 & 59.10 & 2.96 & 0.121 \\
\hline Intensification of agriculture & 140.84 & 2.76 & 0.179 & 242.71 & 12.16 & 0.495 \\
\hline Extensification of agriculture & $2,936.44$ & 57.63 & 3.723 & 295.56 & 14.81 & 0.603 \\
\hline Afforestation & $1,289.11$ & 25.30 & 1.634 & 772.92 & 38.74 & 1.577 \\
\hline Deforestation & 548.39 & 10.76 & 0.695 & 557.99 & 27.97 & 1.138 \\
\hline \multirow[t]{3}{*}{ Construction of water bodies } & 18.74 & 0.37 & 0.024 & 67.03 & 3.36 & 0.137 \\
\hline & 5,09516 & & 6.460 & $1,995.31$ & & 4.071 \\
\hline & \multicolumn{3}{|c|}{ Poland } & \multicolumn{3}{|c|}{ Hungary } \\
\hline LCF & $\begin{array}{c}\text { Area of LCF } \\
{\left[\mathrm{km}^{2}\right]}\end{array}$ & $\begin{array}{l}\text { Percentage } \\
\text { of all LCF [\%] }\end{array}$ & $\begin{array}{l}\text { Percentage of } \\
\text { the country* [\%] }\end{array}$ & $\begin{array}{c}\text { Area of LCF } \\
{\left[\mathrm{km}^{2}\right]}\end{array}$ & $\begin{array}{l}\text { Percentage } \\
\text { of all LCF [\%] }\end{array}$ & $\begin{array}{c}\text { Percentage of } \\
\text { the country* }[\%]\end{array}$ \\
\hline Sub/urbanisation & 250.49 & 9.85 & 0.080 & 110.36 & 2.69 & 0.118 \\
\hline Intensification of agriculture & 314.45 & 12.36 & 0.101 & 768.87 & 18.74 & 0.825 \\
\hline Extensification of agriculture & 226.20 & 8.89 & 0.073 & 679.89 & 16.57 & 0.730 \\
\hline Afforestation & 793.15 & 31.17 & 0.254 & $1,709.27$ & 41.66 & 1.835 \\
\hline Deforestation & 874.12 & 34.35 & 0.280 & 788.87 & 19.23 & 0.847 \\
\hline \multirow[t]{2}{*}{ Construction of water bodies } & 86.06 & 3.38 & 0.028 & 46.19 & 1.13 & 0.050 \\
\hline & $2,544.47$ & & 0.816 & $4,103.45$ & & 4.405 \\
\hline
\end{tabular}

* Area of countries in region of Central Europe: Czech Republic - 78,876.29 km²; Slovakia - 49,012.99 km²; Poland - 311,878.56 km²; Hungary $93,164.82 \mathrm{~km}^{2}$. 
Appendix 2 Area of changes in land cover in Central Europe (2000-2006).

\begin{tabular}{|c|c|c|c|c|c|c|}
\hline & \multicolumn{3}{|c|}{ Czech Republic } & \multicolumn{3}{|c|}{ Slovakia } \\
\hline LCF & $\begin{array}{c}\text { Area of LCF } \\
{\left[\mathrm{km}^{2}\right]}\end{array}$ & $\begin{array}{l}\text { Percentage } \\
\text { of all LCF [\%] }\end{array}$ & $\begin{array}{c}\text { Percentage of } \\
\text { the country* [\%] }\end{array}$ & $\begin{array}{c}\text { Area of LCF } \\
{\left[\mathbf{k m}^{2}\right]}\end{array}$ & $\begin{array}{l}\text { Percentage } \\
\text { of all LCF [\%] }\end{array}$ & $\begin{array}{c}\text { Percentage of } \\
\text { the country* [\%] }\end{array}$ \\
\hline Sub/urbanisation & 144.48 & 9.16 & 0.183 & 37.30 & 5.01 & 0.076 \\
\hline Intensification of agriculture & 152.17 & 9.65 & 0.193 & 24.64 & 3.31 & 0.050 \\
\hline Extensification of agriculture & 643.89 & 40.83 & 0.816 & 60.87 & 8.18 & 0.124 \\
\hline Afforestation & 432.21 & 27.41 & 0.548 & 128.40 & 17.26 & 0.262 \\
\hline Deforestation & 198.69 & 12.59 & 0.252 & 491.36 & 66.04 & 1.003 \\
\hline \multirow[t]{3}{*}{ Construction of water bodies } & 5.69 & 0.36 & 0.007 & 1.51 & 0.21 & 0.003 \\
\hline & $1,577.13$ & & 1.999 & 744.08 & & 1.518 \\
\hline & \multicolumn{3}{|c|}{ Poland } & \multicolumn{3}{|c|}{ Hungary } \\
\hline LCF & $\begin{array}{c}\text { Area of LCF } \\
{\left[\mathbf{k m}^{2}\right]}\end{array}$ & $\begin{array}{l}\text { Percentage } \\
\text { of all LCF [\%] }\end{array}$ & $\begin{array}{c}\text { Percentage of } \\
\text { the country* [\%] }\end{array}$ & $\begin{array}{c}\text { Area of LCF } \\
{\left[\mathrm{km}^{2}\right]}\end{array}$ & $\begin{array}{l}\text { Percentage } \\
\text { of all LCF [\%] }\end{array}$ & $\begin{array}{c}\text { Percentage of } \\
\text { the country* [\%] }\end{array}$ \\
\hline Sub/urbanisation & 254.81 & 13.98 & 0.082 & 191.15 & 7.22 & 0.205 \\
\hline Intensification of agriculture & 132.59 & 7.27 & 0.043 & 407.79 & 15.39 & 0.438 \\
\hline Extensification of agriculture & 64.32 & 3.53 & 0.021 & 158.73 & 5.99 & 0.170 \\
\hline Afforestation & 606.32 & 33.26 & 0.194 & $1,100.44$ & 41.53 & 1.181 \\
\hline Deforestation & 719.81 & 39.49 & 0.231 & 760.65 & 28.71 & 0.816 \\
\hline \multirow[t]{2}{*}{ Construction of water bodies } & 45.04 & 2.47 & 0.014 & 30.78 & 1.16 & 0.033 \\
\hline & $1,822.89$ & & 0.584 & $2,649.54$ & & 2.844 \\
\hline
\end{tabular}

* Areas of the countries in Central Europe: Czech Republic - 78,876.29 km²; Slovakia - 49,012.99 km²; Poland - 311,878.56 km²; Hungary - 93,164.82 $\mathrm{km}^{2}$.

Appendix 3 Proportion of causes of changes in land cover in the different clusters (1990-2000**.

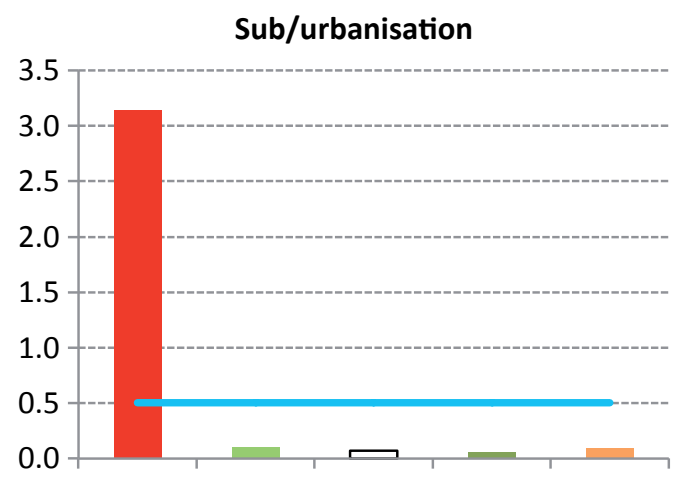

cluster 1 cluster 2 cluster 3 cluster 4 cluster 5

Extensification of agriculture

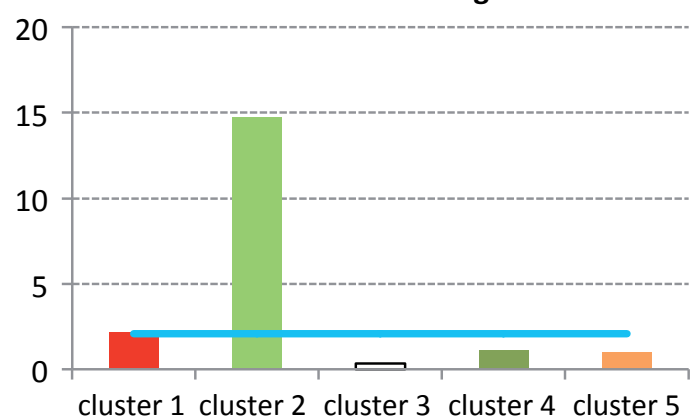

Intensification of agriculture

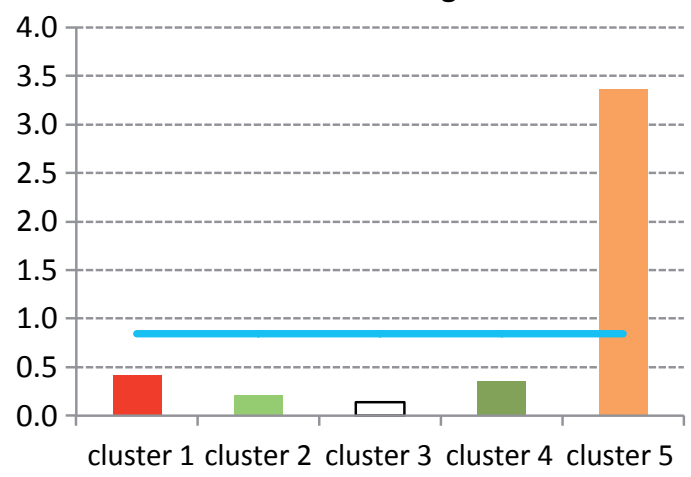

Afforestation

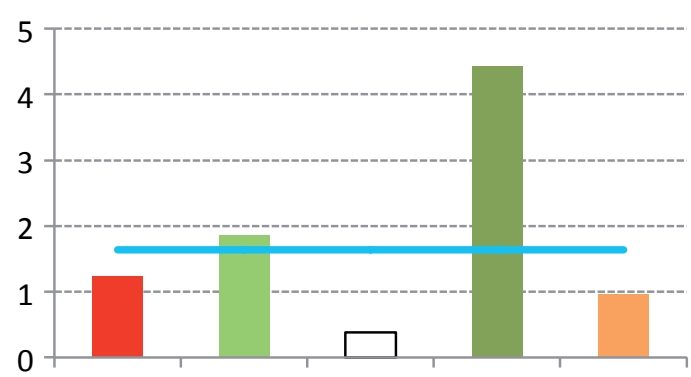

cluster 1 cluster 2 cluster 3 cluster 4 cluster 5

European Journal of Environmental Sciences, Vol. 7, №. 1 


\section{Deforestation}

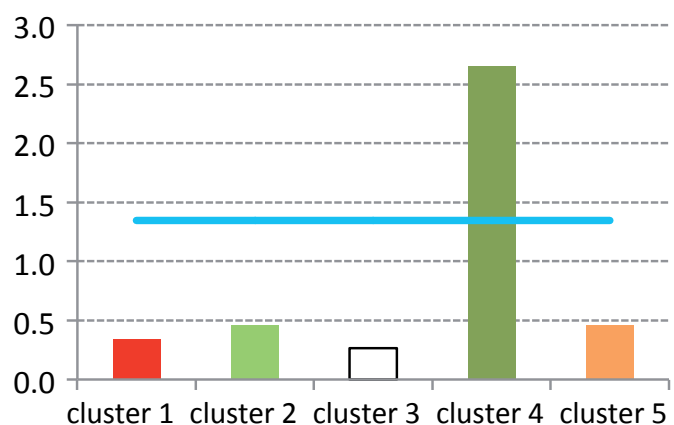

Construction of water bodies

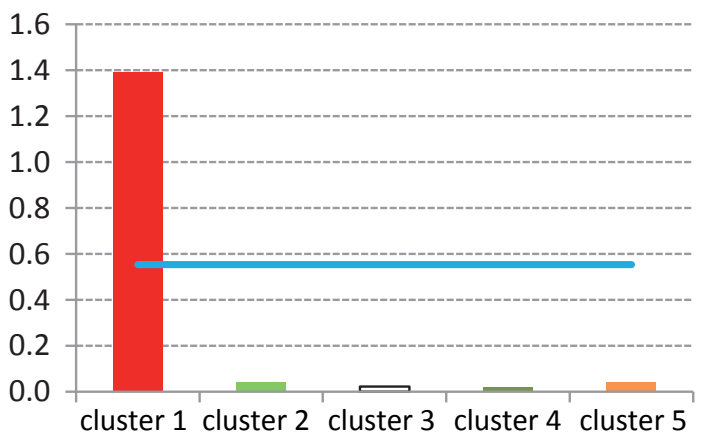

* Horizontal line indicates the average proportion of non-zero values for each of the processes in the different clusters.

Appendix 4 Proportion of the causes of the changes in land cover in the different clusters (2000-2006).

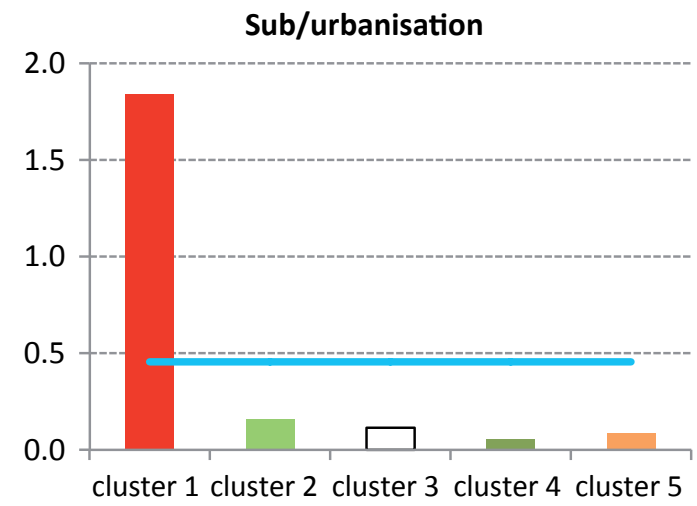

Deforestation

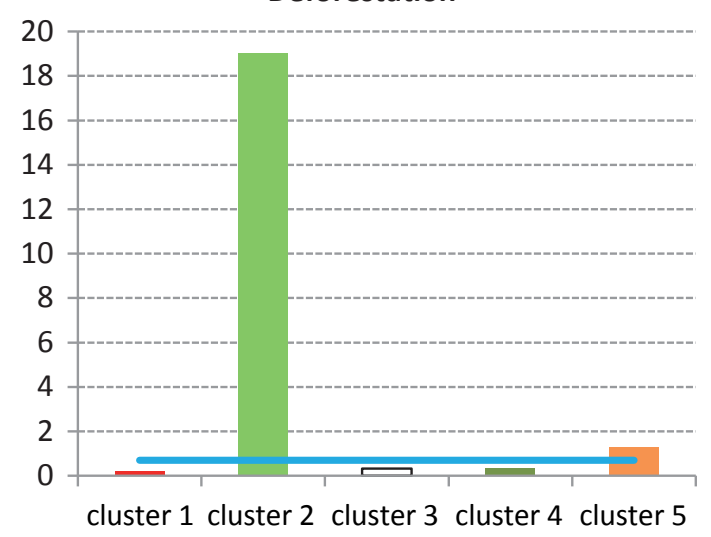

Afforestation

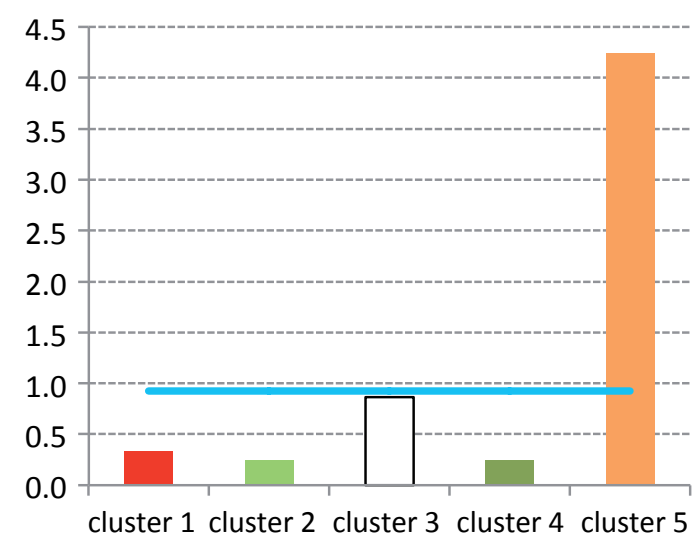

Intensification of agriculture

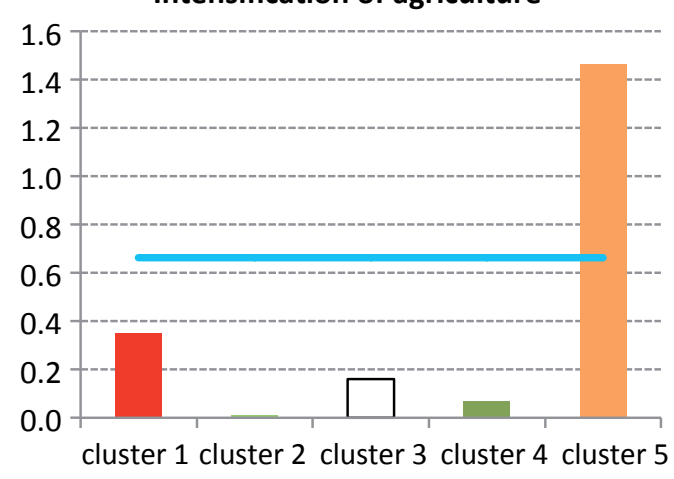

Extensification of agriculture
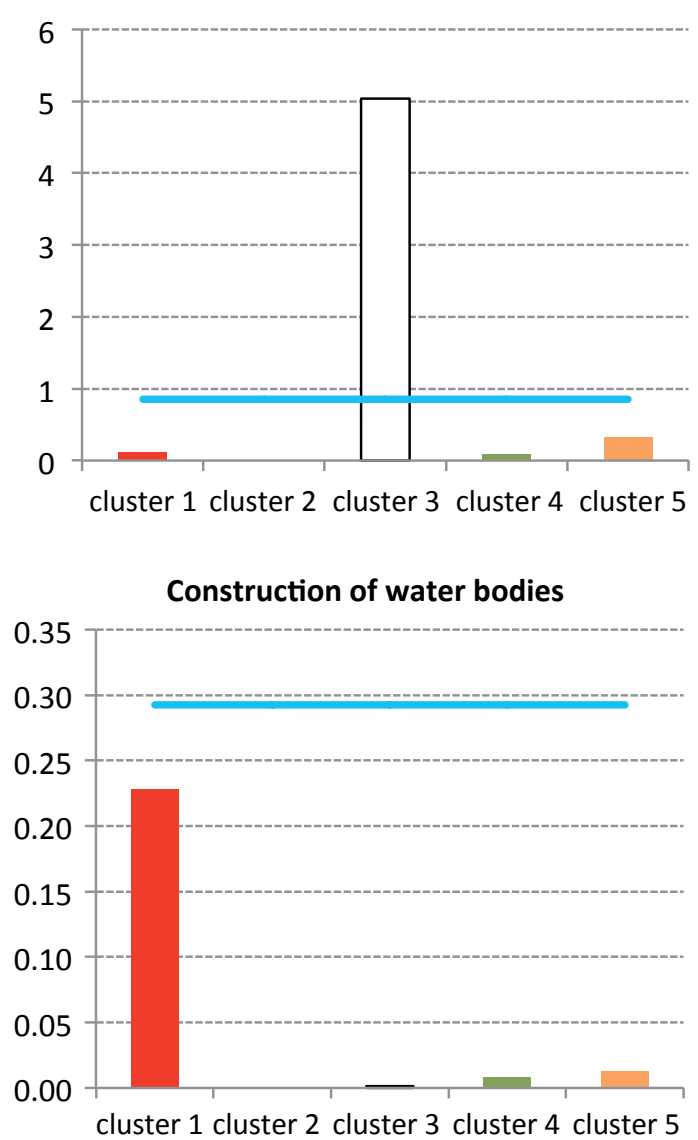

* Horizontal line on the graphs indicates the average proportion of non-zero values for each of the process in the different clusters. 